\title{
Parental investment matters for maternal and offspring immune defense in the mouthbrooding cichlid Astatotilapia burtoni
}

\author{
Isabel S. Keller ${ }^{1}$, Walter Salzburger ${ }^{2}$ and Olivia Roth ${ }^{1 *}$ (D)
}

\begin{abstract}
Background: Parental care, while increasing parental fitness through offspring survival, also bears cost to the care-giving parent. Consequentially, trade offs between parental care and other vitally important traits, such as the immune system seem evident. In co-occurring phases of parental care and immunological challenges negative consequences through a resource allocation trade off on both the parental and the offspring conditions can be predicted. While the immune system reflects parental stress conditions, parental immunological investments also boost offspring survival via the transfer of immunological substances (trans-generational immune priming).

We investigated this relationship in the mouthbrooding East African cichlid Astotatilapia burtoni. Prior to mating, females were exposed to an immunological activation, while others remained immunologically naive. Correspondingly, the immunological status of females was either examined directly after reproduction or after mouthbrooding had ceased. Offspring from both groups were exposed to immunological challenges to assess the extent of trans-generational immune priming. As proxy for immune status, cellular immunological activity and gene expression were determined.

Results: Both reproducing and mouthbrooding females allocate their resources towards reproduction. While upon reproduction the innate immune system was impeded, mouthbrooding females showed an attenuation of inflammatory components. Juveniles from immune challenged mouthbrooding females showed downregulation of immune and life history candidate genes, implying a limitation of trans-generational plasticity when parents experience stress during the costly reproductive phase.

Conclusion: Our results provide evidence that both parental investment via mouthbrooding and the rise of the immunological activity upon an immune challenge are costly traits. If applied simultaneously, not only mothers seem to be impacted in their performance, but also offspring are impeded in their ability to react upon a potentially virulent pathogen exposure.
\end{abstract}

Keywords: Parental care, Sexual dimorphism, Trans-generational immune priming, Immune system, Teleosts, Phenotypic plasticity, Gene expression

\section{Background}

Males and females differ in their strategies of how to transfer genetic material to the next generation during reproduction [82]. Males produce mobile sperm just big enough to carry the genetic material, while females produce comparably large eggs that contain all necessities for embryogenesis [84]. Important consequences of this anisogamy are a higher maternal investment per reproductive unit and sex-specific evolutionary best reproductive

\footnotetext{
*Correspondence: oroth@geomar.de

${ }^{1}$ Evolutionary Ecology of Marine Fishes, GEOMAR - Helmholtz Centre for

Ocean Research, Kiel, Germany

Full list of author information is available at the end of the article
}

strategies [49, 93]. Because male fitness is limited by the number of mating events, males tend to primarily invest into the display of sexual signals such as ornaments to enhance their attractiveness [36]. Female fitness, on the other hand, is limited by the number of reproductive units [7]. According to Bateman's principle, females are thus selected to prolong their life span $[7,20,93]$, which can be achieved by a more efficient immune defence and pathogen evasion strategy $[48,65,71,75,80]$. This, in turn, leads to a sexual immune dimorphism, since the males' investment into secondary sexual signals is often at the expense of investing into immune defense (in the form of a resource allocation trade-off) $[10,72,78,85]$. 
Sex-specific evolutionary strategies also exist for the extent of parental care [49]. This can additionally challenge or, alternatively, compensate the imbalance in investment per reproductive unit between females and males. An increased parental investment reduces the prospect of remating and therefore impedes the overall reproductive success of males and females alike [34, 93]. Importantly, the caregiving sex is more limited in the number of reproductive units during its lifetime [93]. This implies that sexual immune dimorphism and parental investment, both fitness related traits, are intermingled. As consequence, parents face a resource allocation trade-off between investment in future reproduction and investment in selfmaintenance and immune defense [47, 71]. Due to high energy expenditure during parental care, most vertebrates show immunosuppression, loss of energy stores, micronutrient depletion, glucocorticoid stress response and/or oxidative stress $[13,29,66]$.

Parents may also transfer non-genetic information about their environmental experience to their offspring, which provides the opportunity for adaptive trans-generational phenotypic plasticity $[46,60]$. Such parental effects can influence offspring development, and induce epigenetic changes triggering differential gene expression in the offspring $[4,41,98]$. As a cross-generational inducible defense strategy, parents transfer information about the concurrent pathogen assembly in the environment (trans-generational immune priming (TGIP)) $[1,33]$. In vertebrates, TGIP enables coping with pathogens when the offspring immune system is not yet fully functional $[32,38]$. This can induce a faster maturation and thereby enhance fitness [95]. Mechanisms how parents prime their offsprings' immune system are manifold [88]. Transfer of immune components, such as immunoglobulin M (IgM), complement components, proteins and enzymes via the egg has already been shown in fishes $[3,11,59,87,89]$.

In addition to a direct immunological transfer via the egg, immunological information can also be transferred from parent to offspring through intimate contact with immune reactive tissues, such as mucus [31, 67, 79]. In cichlid fishes such as the discus fish or tilapia, offspring are micro nipping mucus from the parental epidermis during the entire free-swimming stage $[18,44]$. Transfer of immunity to the next generation may explain the induced immunological activity (IgM and antimicrobial peptides) in the parental mucus. In line with this, immune relevant components are passed on via mouthbrooding in tilapia [79] when eggs and fry are guarded in the buccal cavity of the parents in close contact with the parental mucosa [44]. Mouthbrooding is a rather costly parental investment trait, as it challenges the parental cardiac and the ventilation system resulting in higher osmoregulation [68] followed by a drop of parental body condition [35]. Mouthbrooding fishes are thus hypothesized to face a resource allocation trade-off between brooding and other life-history traits, among them the immune system. The close contact between parents and offspring and limited options for food-uptake during mouthbrooding makes cichlids an excellent system to study the costs of parental care for the parents' immune system and the possibility for TGIP via the eggs and via the buccal mucosa.

In this study, we investigated the trade-off between parental care and immunological activation in the East African cichlid Astatotilapia burtoni, a maternal mouthbrooder inhabiting Lake Tanganyika and its surroundings [26, 90, 91]. A. burtoni is a model species for various questions in the field of evolutionary biology and development (brain and eye development [56]; hormonal, behavioral and phenotypic adaptation [23, 24, 39, 40, 42, 45, 92]; immune gene expression analysis upon challenge with Vibrio anguillarum [22]; as well as genomics and transcriptomics $[5,14,76,77]$.

The first part of this study was designed to assess the costs associated with mouthbrooding and reproduction and its effect on the capability of mounting an immune response in adults. Therefore, we assigned immune challenged and immunologically naïve female $A$. burtoni to either mouthbrooding, only reproduction without mouthbrooding, or neither reproduction nor brooding ('no reproduction'). Immune challenged females are hypothesized to suffer a severe resource allocation trade-off between mounting an immune response and investing in reproduction and brooding. We thus expected a gradually decreasing immune response from 'no reproduction' over 'reproduction only' to 'mouthbrooding'. To evaluate how maternal investment affects sexual immune dimorphism also naïve male immune status was examined. Males were hypothesized to having a lower immune competence than non-brooding females, however, with rising costs of parental investment (i.e. reproduction and mouthbrooding), whereas female immunological activity was expected to decrease, diminishing the difference between the sexes.

In the second part of the study, we focused on the offspring from immunologically challenged and naïve mothers. To this end, offspring were either artificially raised or mouthbred and then examined for their immunological activity to address the existence and specificity of TGIP via the buccal mucosa during mouthbrooding. We hypothesized that immune components are transferred from the mother to the offspring not only directly via the egg but also additionally during mouthbrooding. Juveniles raised in the absence of the female were supposed to be less immune competent than juveniles bred within the buccal cavity of the female. To assess if parents can transfer specific immune components about the concurrent pathogens in the environment, juveniles were vaccinated with either the same (homologous), a distinct (heterologous), or no 
bacteria isolate as their mothers were already immunologically exposed to. If TGIP is specific, offspring from challenged females should show a higher immune competence after challenge with the homologous bacteria than heterologous challenged offspring and offspring from naïve females. Mouthbrooding provides the opportunity for a prolonged transfer of immune components through the buccal mucosa during the whole larval development. Therefore, mouthbred offspring were supposed to show a higher immunological activity than artificially raised offspring.

\section{Methods}

I. Cost of mouthbrooding on Astatotilapia burtoni females immune defence \& II. Cost of reproduction and influence on sexual immune dimorphism in Astatotilapia burtoni

This experiment was designed to assess the costs of reproduction and mouthbrooding on the immune competence of females, and the impact of reproduction and mouthbrooding on a potential sexual immune dimorphism in the cichlid fish Astatotilapia burtoni. We immunologically challenged 35 female Astatotilapia burtoni by peritoneal injection of $50 \mu \mathrm{l}$ of either $10^{8}$ heat-killed $\left(65^{\circ} \mathrm{C}\right.$ for $60 \mathrm{~min}$ ) Vibrio anguillarum (strain S6 M4, isolated from pipefish gut; (JQ598664 recombinase A (recA) gene partial cds) [73] diluted in PBS) $(+, n=18)$ or PBS $(-, n=17)$ as control. As the injected bacteria were heat-killed, this treatment served as an immunological activation similar to a vaccination. Hence, no clinical symptoms were observed and no animal died after the challenge. According to their immune challenge, females were tagged subcutaneously with Visible Implant Elastomer Tags (VIE; Northwest Marine Technology, Inc; red and green fluorescent tags). After challenge and tagging, females were randomly placed in groups of three to four animals independent of their challenge in $80 \mathrm{l}$ aquaria (from here on named "mating tanks"). Fish were held in in a circulation system at $26{ }^{\circ} \mathrm{C}$ with a $12 \mathrm{~h}$ day/12 $\mathrm{h}$ night light regime and fed daily with thawed out brine shrimp nauplii. One male per tank (1:34 , male to female ratio) was introduced after allowing the females to acclimatize for one week. In the reproduction treatment $(\mathrm{R})$, females were allowed to reproduce, but eggs were stripped the day after fertilization ( 6 females with priming $\left(R_{+}\right), 5$ females naïve $\left.\left(R_{-}\right)\right)$. In the control treatment $(\mathrm{C})$, females were prevented from reproduction (7 females with priming $(C+), 7$ naïve females $(C-)$ ). In the brooding treatment $(\mathrm{B})$, females were allowed to breed naturally until juveniles left the mouth of the female (7 females with priming $(\mathrm{B}+)$; 7 naïve females $(\mathrm{B}-))$. At the first sign of egg uptake after fertilization, females were transferred to $10 \mathrm{l}$ aquaria with one fish per tank in a climate chamber (set to $28{ }^{\circ} \mathrm{C}$ air temperature and resulting in $26{ }^{\circ} \mathrm{C}$ water temperature) and randomly assigned to one of three treatments: Females of the reproduction treatment (R) were immediately stripped off their eggs, challenged and sampled $24 \mathrm{~h}$ after challenge. Females of the brooding treatment (B) were kept in the $10 \mathrm{l}$ aquaria until the free-swimming juveniles were released from the buccal cavity after about 14 days, challenged and sampled $24 \mathrm{~h}$ later. Four females $(2 \times \mathrm{B}-/ 2 \times \mathrm{B}+)$ lost their eggs during brooding and were excluded from the experiment, thus lowering sample size to 31 females ('reproduction': 6 females with priming $(\mathrm{R}+), 5$ females naïve $(\mathrm{R}-))$, 'control' $(\mathrm{C})$ : 7 females with priming $(\mathrm{C}+), 7$ naive females $(\mathrm{C}-)$,' brooding' (B) 5 females with priming $(\mathrm{B}+) ; 5$ naïve females (B-)). Females of the control treatment were randomly chosen and transferred to the climate chamber and either sampled $24 \mathrm{~h}$ after transfer (control for the reproduction females) or 14 days after transfer (control for the brooding females). Males were sampled after the last female of the tank had been transferred to the climate chamber (Fig. 1 a and b, roman letters (I., II. \& III.) guide through results and discussion).

\section{Impact of maternal immune challenge on mouthbreed Astatotilapia burtoni}

Here, we examined the effects of mouthbrooding on the immune system of the offspring and tested for the existence and specificity of trans-generational immune priming (TGIP) in A. burtoni via the eggs and via the buccal mucosa during mouthbrooding. To examine TGIP, we vaccinated virgin females with either Phosphate buffered saline (PBS) (-) or heat-killed Vibrio anguillarum in PBS $(+)$. The latter induces the maternal immune system simulating a potential infection. Juveniles from the brooding treatment (B) were naturally bred until they left the buccal cavity of the female after about 14 days. Clutches from females of the reproduction treatment were raised separately in a breeding apparatus designed to keep the eggs in motion and aerated through an indirect water flow until the yolk sack was used up completely (after about 14 days). All breeding chambers were located in the same 101 aquaria. Both, artificially raised and naturally bred juveniles were grown for two weeks post fertilization and were then randomly divided in three groups for immune challenge by pricking them with a syringe. To test for possible effects of the maternal challenge $(+/-)$ or the maternal treatment $(\mathrm{R} / \mathrm{B})$ on the juvenile immune gene expression, juveniles from each batch were split into three groups. Group one was pricked, homologously to the maternal challenge, with drops of $10^{10}$ heat-killed $\left(65{ }^{\circ} \mathrm{C}\right.$ for $60 \mathrm{~min}$ ) Vibrio anguillarum (strain S6 M4 diluted in PBS); group two was challenged heterologous to the maternal challenge with drops of $10^{10}$ heat-killed $\left(65^{\circ} \mathrm{C}\right.$ for $60 \mathrm{~min}$ ) Tenacibaculum maritimum (diluted in PBS), and group three with $1 \mu \mathrm{l}$ of PBS (Fig. 1 a and $b$, roman letters guide through results and discussion). As juveniles were too small to be tagged, they were held in 


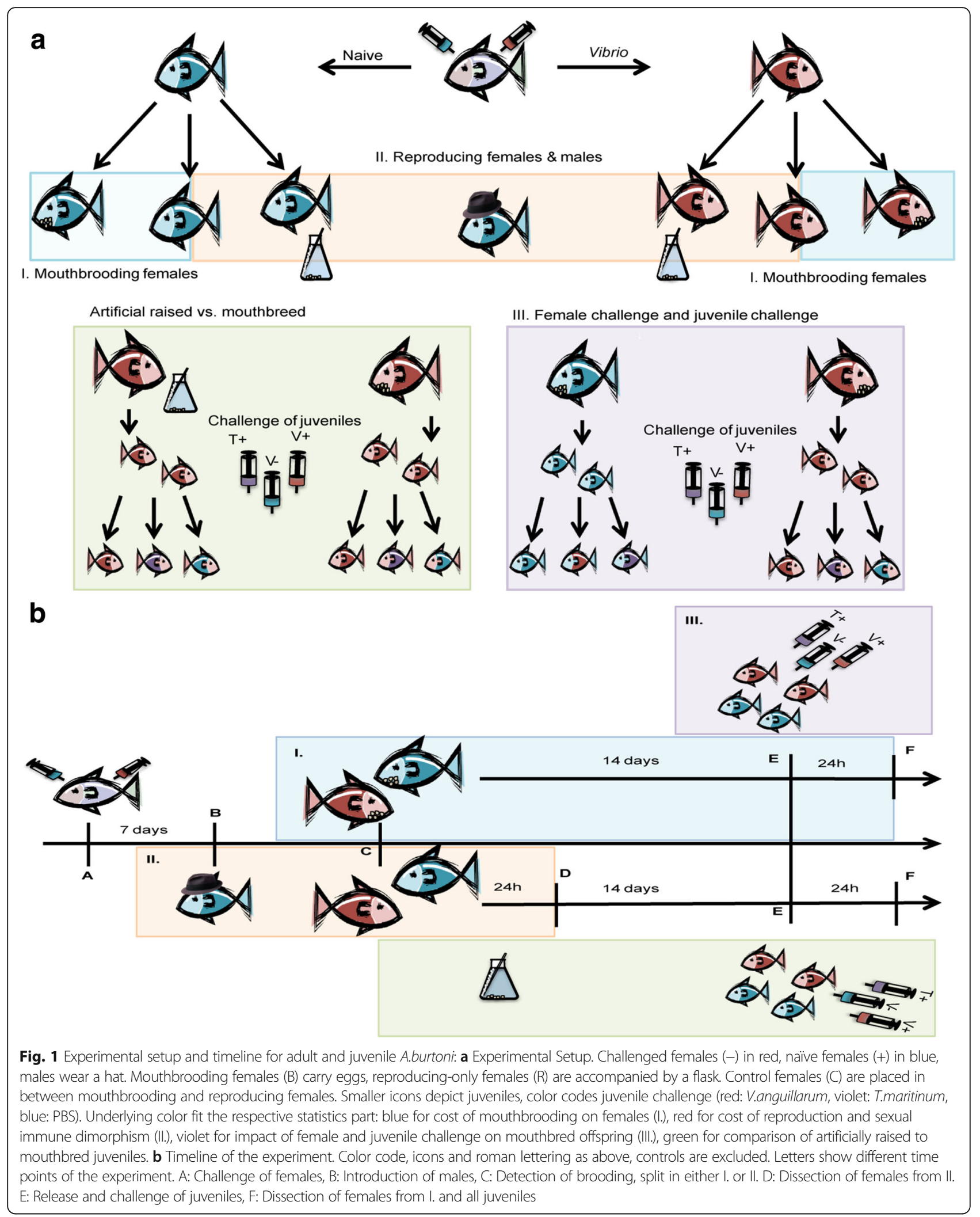


21 aquaria according to their treatment and sampled the next day.

\section{Fish handling}

All fish were killed by bathing in an overdose of MS222 (according to animal welfare permit MELUR V 312-72 24.121-19 (67-5/13), "komparative Vergleichsstudie von Immunantwort-Transfer von Eltern zu Nachkommen in Fischarten mit extremer Brutpflege"). In adult fish, we measured total length (TL), standard length (SL), and weight $(\mathrm{W})$ of all adult fish in order to calculate a condition factor as a proxy for fitness $\left(\mathrm{K}=\mathrm{W} / \mathrm{TL}^{3}\right)$. For the adult gene expression analyses gills were dissected and stored in RNAlater. The three main immunological organs of fish [96] were used for the assessment of the cellular immune measurements: blood was taken as a proxy for systemic infections and transportation way of pathogens; the head kidney as main lymphocyte proliferation organ; and the spleen as blood filtration and pathogen neutralization organ. Juvenile fish were measured for total length and weight. For the gene expression analysis, the head was separated from the rest of the body and stored in RNAlater. We could not measure cellular immune parameters in juveniles, as they were too small for organ dissection.

\section{Cellular immune parameter analysis}

In order to compare immune dynamics and activation of immune response among the different female treatments and challenges, Flow Cytometric measurements of cell population and adaptive immune cell proliferation were conducted. Measurements were done with a BD Accuri C6 Flow Cytometer following the protocols described in Roth et al. [72] with modifications for cichlids described in Diepeveen et al. [22]. After dissection, spleen and head kidney were individually smashed through $40 \mu \mathrm{m}$ cell sieves (Falcon) and suspended in $500 \mu \mathrm{l} \mathrm{RPMI-1640}$ cell medium (Sigma-Aldrich, diluted with 5\% distilled $\mathrm{H}_{2} \mathrm{O}$ ). Blood was collected from the caudal vein and diluted in $500 \mu \mathrm{l}$ RPMI-1640 cell medium. For cell population measurement, $75 \mu \mathrm{l}$ of live cells in suspension were mixed with $50 \mu \mathrm{l}$ Propidium Iodide $(20 \mu \mathrm{g} / \mathrm{ml}$, Roth) and measurements were taken immediately after. Cell size (Forward scatter, FSC) and cell complexity (Side scatter, SSC) of up to 10'000 life cell counts per sample were recorded on slow flow rate. Lymphocytes (smaller cells with low complexity) and monocytes (larger cells with higher complexity) were distinguished based on their scatter pictures on the basis of their distinct morphology. For cell cycle analysis, $75 \mu \mathrm{l}$ of living cells in suspension were killed with $75 \mu \mathrm{l}$ of $70 \% \mathrm{EtOH}$ and stained with $50 \mu \mathrm{l}$ Propidium Iodide. The cell mixture was measured for up to $20^{\prime} 000$ individual cell counts on medium flow rate. Cells in a dividing stage of the cell cycle ( $\mathrm{S}-$ or $\mathrm{G}_{2} / \mathrm{M}$-phase) have approximately double the DNA content than cells in a resting stage of the cell cycle $\left(G_{1}\right.$-phase), allowing the discrimination of active and resting cells according to the measured emission of red fluorescence of the Propidium Iodide binding to the cellular DNA of each cell. Flow cytometric measurements were analysed using predefined gating in the BD Accuri C6 Software (Version 1.0.264.21).

\section{Gene expression assays}

RNA from juveniles and adult gill samples were extracted with RNeasy 96 Universal Tissue Kit (Qiagen) following the manufacturers protocol for vacuum extraction. RNA yield was measured by spectrometry (NanoDrop ND-1000; peQLab) and $300 \mathrm{ng} / \mu \mathrm{l}$ was used for reverse transcription with QuantiTect ${ }^{\circ}$ Reverse-Transcription Kit (Qiagen). Some samples (adults: 2 females $\mathrm{B}+, 1$ female $\mathrm{R}+, 2$ females $\mathrm{B}-$, juveniles: 2 juveniles $\mathrm{V}+$ from $\mathrm{V}+$ females, 2 juveniles $\mathrm{V}+$ from naïve females, $2 \mathrm{~T}+$ juveniles from naïve females, 8 naïve juveniles from naïve females) were excluded from the gene expression analysis due to low RNA yields. In order to design cichlid specific primers for immune genes, we blasted immune relevant teleost gene sequences against an Astatotilapia burtoni reference transcriptome [5]. Sequences of those genes were then uploaded in the web based Primer3 software (Version 4.0.0) for primer picking. Primers were tested for specificity and efficiency with RT qPCR using $5 \times$ HOT FIREPol $^{\circ}$ EvaGreen ${ }^{\circ}$ qPCR Mix Plus (ROX) (Solis BioDyne). 48 specific primer pairs with efficiencies above $90 \%$ and standard curves with slopes of $\log$ quality vs. threshold cycle (Ct) between -3.5 and 3.2 were then selected for further analyses (list of all primers see Additional file 1: Table S1).

The gene-expression patterns of 48 immune-related genes were measured using a Fluidigm-BioMarkTM system based on 96.96 dynamic arrays (GE-Chip). For pre-amplification of target cDNA a mix of $2.5 \mu \mathrm{l}$ TaqMan PreAmp Master Mix (Applied Biosystems), $0.5 \mu \mathrm{l}$ of $500 \mathrm{nM}$ combined primer pairs (diluted with TE Buffer) and $0.75 \mu \mathrm{l} \mathrm{HPLC} \mathrm{H}_{2} \mathrm{O}$ was used for $1.4 \mu \mathrm{l}$ of cDNA. Mixture was pre-amplified $\left(1 \times 10 \mathrm{~min} ; 95^{\circ} \mathrm{C} ; 16 \times(15 \mathrm{~s}\right.$; $\left.95^{\circ} \mathrm{C}, 4 \mathrm{~min} ; 60^{\circ} \mathrm{C}\right)$ ) and diluted 1:10 with low EDTA-TE Buffer. For the chip run a sample mix with $3.5 \mu \mathrm{l} 2 \times$ SSo FastEvaGreen Supermix with low Rox (BioRad) and $0.37 \mu \mathrm{l} 20 \times$ DNA binding Dye sample loading reagent (Fluidigm) on $3.3 \mu \mathrm{l}$ of pre-amplified 1:10 diluted cDNA and an assay mix with $3.5 \mu \mathrm{l} 2 \times$ Assay loading reagent (Fluidigm) and $3.15 \mu 1 \times$ low EDTA-TE Buffer on $0.7 \mu \mathrm{l}$ of $50 \mu \mathrm{M}$ Primer mix have been prepared. $5 \mu \mathrm{l}$ of each mix were loaded on a GE-chip, and measured with the GE-fast 96.96 PCR protocol in the BioMarkTM system according to Fluidigm instructions. In each Chip run we included two technical replicates, a negative control (HPLC $\mathrm{H}_{2} \mathrm{O}$ ) and a -RT control to test for residual gDNA. 


\section{Data management \& statistics}

All statistical analyses were done in $\mathrm{R}$ version 3.1.3. GUI 1.65 Snow Leopard built (6912). All data were checked for normality and variance homoscedasticity. Wherever needed flow cytometric data were log transformed and gene expression data were cos $(+20)$ transformed to fulfill assumptions for parametric testing.

When analyzing the adult data, we revealed differences among control animals kept in the climate chamber for short term ( $24 \mathrm{~h}$; controls of the reproduction treatment) and those kept in the climate chamber for longer term ( 14 days; controls of the brooding treatment). We thus had to split the adult data (flow cytometric measurements and gene expression of the gills) according to the location where the brooding (B)/ non-brooding (C) (I.) and reproduction (R)/ no reproduction (C) (II.) animals were kept. The controls for the brooding treatment and the mouthbrooding females (I.) were therefore analysed separately from the controls for the reproduction treatment and the reproduction only females and males (II.). All females used as control (C) were neither reproducing nor brooding. Our analysis is thus restricted to interpretations regarding 'mouthbrooding' versus 'brooding control' and 'reproduction' versus 'reproduction control', while mouthbrooding females cannot be directly compared to the reproduction only females. Males were sacrificed $24 \mathrm{~h}$ after their last reproductive event, handling was thus most similar to the reproduction females. Males are thus in the statistical comparison included in the comparison between reproduction and no reproduction (II.).

Due to high mortalities in juveniles reared artificially and descending from naïve reproduction only females (R-) (only 1 juvenile survived), we had to exclude all juveniles reared artificially from the analysis even though survival rate did not differ between the treatments (ANOVA of total juvenile number per female (naïve or challenged) at the end of two weeks mouthbrooding or artificial raising; $\left.\mathrm{F}_{3 / 17}=1.701, p=0.205\right)$. Thus in the juvenile data set (III.), we only compared mouthbred juveniles from challenged females to those from naïve females, which permitted to determining the effect of maternal immune challenge on juvenile condition and to assessing the transfer of immunological information.

Cellular immune parameter data were composed to flow cytometric measurements of cell populations and cell proliferation of adult fish (I. \& II.). Cell populations were measured as the relative proportion of lymphocyte (l) and monocyte (m) counts to the total of live cells. Cell proliferation shows the relative proportion of cells in dividing- (s) or in resting phase ( $\mathrm{r}$ ) to single cells in total. We calculated the proportion of both lymphocytes to monocytes $(1 / \mathrm{m})$ and dividing- to resting phase $(\mathrm{s} / \mathrm{r})$ for statistical analysis. Samples with a live cell count lower than $10 \%$ of total events were removed from the analysis. Data were analysed using an ANCOVA with the two factors treatment and challenge and the condition factor $(\mathrm{K})$ as a covariate $(\operatorname{aov}(x \sim$ treatment*challenge $+K))$. For both adult datasets (I. \& II.), the same model was used. Whether the random factor "mating tank" influences the results was tested in an initial ANOVA model. As the random factor was not significant, it was excluded from the final model. Tukey HSD (95\% family-wise confidence levels) served as post hoc test if necessary.

Data from the gene expression analysis were processed using the Fluidigm-integrated software (Fluidigm Real-Time PCR analysis; BioMark Version 4.1.2). Samples with melt curves that deviated in mean temperature from the mean melt curve per gene were excluded. Mean cycle threshold (Ct), standard deviation (SD), and coefficient of variance (CV) were calculated for each remaining sample duplicate. Samples with a CV lower than $4 \%$ were replaced by the mean value over all samples per gene. One gene (HA_PCAF; histone acetyltransferase) was removed, as too many samples did not sufficiently match the criteria mentioned above. HIVEP $3 b$ and ADNPB had the lowest geNorm (qbase + version 3.0, biogazelle) values, which indicates that they were most constant over all treatments, and were thus chosen as reference genes. For relative gene expression, the geometric mean of these two reference genes (HIVEP $3 b$ and $A D N P B$ ) was subtracted from the mean $\mathrm{Ct}$ value of the gene of interest per sample resulting in $\Delta \mathrm{Ct}$ values. This was done for the gene expression data from juveniles and adults in the same way. Genes were grouped according to their function (GO terms; UniProt [6]) for multivariate statistics (Table 1).

Statistical analysis of adult gene expression was done calculating a PERMANCOVA with challenge and treatment as factors and condition factor $(\mathrm{K})$ as covariable for each gene group (adonis( $x \sim$ treatment*challenge $+K$, method = "euclidean", permutations =1000)). The same formula was applied for all adult datasets (brooding/ non-brooding gills (I.) \& reproduction/no reproduction gill (II.)). For significant PERMANCOVA factors, univariate analyses served as post hoc tests to identify the impact on each gene. These ANCOVAs used the same model $\left(\operatorname{aov}\left(x \sim\right.\right.$ treatment ${ }^{*}$ challenge $\left.\left.+K\right)\right)$ and a Tukey HSD test if necessary, to depict the direction of the differences among treatments (as done in [9]). To address the gene expression of juvenile cichlids (III.), we included family in the model, as some of the samples are siblings and therefore not independent we performed a nested MANOVA with female treatment nested in family [74]. Significant data were then post hoc tested in a nested ANOVA with the same factors as for the MANOVA (anova (x jtreatment *ftreatment + ftreatment\%in\%family)). Further post hoc testing was done with Tukey HSD. 
Table 1 Division of candidate genes in functional groups

\begin{tabular}{|c|c|c|c|c|c|}
\hline \multicolumn{3}{|l|}{ Gene Group } & \multirow{2}{*}{$\begin{array}{l}\text { Gene Name } \\
\text { Fibronectin beta antigen CD29 }\end{array}$} & \multirow{2}{*}{$\begin{array}{l}\text { Gene Group } \\
\text { Metabolism }\end{array}$} & \multirow{2}{*}{$\begin{array}{l}\text { Gene Name } \\
\text { Proprotein convertase subtilisin }\end{array}$} \\
\hline All Immune System & \multirow{9}{*}{\multicolumn{2}{|c|}{$\begin{array}{l}\text { Adaptive Immune } \\
\text { System }\end{array}$}} & & & \\
\hline & & & Fibronectin beta antigen CD81 & & Elongation Factor 1 \\
\hline & & & Ig light chain & & Ribosomal protein A3 \\
\hline & & & Interleukin 10 & Sex related genes & Androgen receptor $\mathrm{A}$ \\
\hline & & & Integrin alpha 2 & & Androgen receptor B \\
\hline & & & MHC I antigen F10 alpha chain & & Aromatase B \\
\hline & & & $\mathrm{MHC} \| \mathrm{b}$ & Epigenetic genes & DNA methyltransferase 1 \\
\hline & & & Lymphocyte cytosolic factor I & & Histone acetyltransferase \\
\hline & & & IgG FC binding protein & & Histone deacetylase \\
\hline & \multirow{17}{*}{$\begin{array}{l}\text { Innate immune } \\
\text { system }\end{array}$} & \multirow[t]{5}{*}{ Inflammation } & Allograph inflammation factor & & Histone demethylase \\
\hline & & & Coagulation factor II /Thrombin & & histone lysine methyltransferase \\
\hline & & & Chemokine receptor 9 & & Lysine specific demethylase \\
\hline & & & Lectine & Development & Myogenic regulatory factors \\
\hline & & & Tumor necrose factor beta & & Early growth response 1 \\
\hline & & \multirow[t]{3}{*}{ Oxidative Stress } & Catalsase & & Growth hormone rh \\
\hline & & & Copper zink dismutase & & Opsin 1 \\
\hline & & & Trypsin I & Stress & Heat shock protein 70 \\
\hline & & \multirow[t]{5}{*}{ Various innate IS } & Calreticulin 3 & & Heat shock protein 90 \\
\hline & & & Calreticulin 1 & & Glucocorticoid receptor \\
\hline & & & FAM60 A Protein & & Heat shock protein 60 \\
\hline & & & Pentraxin 4 & Reference & Activity-dep neuroprotector \\
\hline & & & Serum amyloid $A$ & & Hivep 3b \\
\hline & & \multirow{2}{*}{$\begin{array}{l}\text { Complement } \\
\text { Components }\end{array}$} & Complement component 1q & & \\
\hline & & & Complement component 9 & & \\
\hline & & \multirow[t]{2}{*}{ Antimicrobial Peptides } & Hepcidin & & \\
\hline & & & Latescidin 2 & & \\
\hline
\end{tabular}

\section{Results}

\section{Cost of mouthbrooding on Astatotilapia burtoni female immune defence}

To assess costs of mouthbrooding, challenged and naïve mouthbrooding females were compared to challenged and naïve control females, which were neither brooding nor reproducing. Brooding was successful in five of seven naïve and five of seven Vibrio challenged females (four females $(2 \times \mathrm{B}-/ 2 \times \mathrm{B}+)$ lost their brood within two weeks). Mouthbrooding influenced both the proportion of adaptive to innate immune cells and the activity of the adaptive immune system in the head kidney. Brooding females had a higher proportion of adaptive to innate immune cells, whereas the proportion of active adaptive immune cells was lowered during brooding. Immune challenge had no effect on both cellular immune parameters (Table 2; Fig. 2 a and b).

Overall gene expression of the gill tissue was affected in three gene groups; inflammation genes (univariate effects in lectine, chemokine receptor 9 \& thrombin receptor), general innate immune system genes (univariate effects in catalase) and genes involved in stress response (univariate effects in glucocorticoid receptor). The interaction of mouthbrooding and immune challenge downregulated the expression of lectine and chemokine receptor 9 compared to the naïve treatments (C- \& B-) (Fig. 3a). Challenge alone $(\mathrm{C}+)$ had no effect on the expression of both lectine and chemokine receptor 9. Mouthbrooding females have a lower expression of both thrombin receptor like 1 and glucocorticoid receptor (Fig. 3b). Immune challenge with Vibrio downregulated the expression of thrombin receptor like 1 and catalase (Multivariate: Table 3; Fig. 3c; Univariate Additional file 2: Table S2, Tukey HSD: Additional file 3: Table S3).

\section{Cost of reproduction and influence on sexual immune dimorphism in Astatotilapia burtoni}

Comparing immune challenged and naïve reproducing with immune challenged and naïve non-reproducing control females allows assessing the cost of reproduction 
Table 2 Two-way ANCOVA results of cellular immune parameter from brooding vs. non-brooding females: Significant $p$ values $(p<0.05)$ are marked in bold letters. Results from Tukey HSD posthoc tests can be found in Additional file 2: Table S2

\begin{tabular}{|c|c|c|c|c|c|c|c|c|c|c|c|c|c|}
\hline & \multirow[b]{2}{*}{ Df } & \multicolumn{4}{|l|}{ Blood } & \multicolumn{4}{|c|}{ Spleen } & \multicolumn{4}{|c|}{ Head Kidney } \\
\hline & & SS & MS & F value & $\operatorname{Pr}(>F)$ & SS & MS & F value & $\operatorname{Pr}(>F)$ & SS & MS & F value & $\operatorname{Pr}(>F)$ \\
\hline \multicolumn{14}{|l|}{ Lymphocyte/Monocyte } \\
\hline Treatment & 1 & 0.017 & 0.017 & 0.89 & 0.378 & 0.70 & 0.70 & 2.11 & 0.190 & 4.30 & 4.30 & 5.62 & 0.050 \\
\hline Challenge & 1 & 0.008 & 0.008 & 0.43 & 0.531 & 0.07 & 0.07 & 0.20 & 0.667 & 0.07 & 0.07 & 0.09 & 0.775 \\
\hline Condition factor & 1 & 0.018 & 0.018 & 0.94 & 0.364 & 0.01 & 0.01 & 0.03 & 0.861 & 0.10 & 0.10 & 0.13 & 0.733 \\
\hline Treatment*Challenge & 1 & 0.006 & 0.006 & 0.34 & 0.580 & 0.07 & 0.07 & 0.21 & 0.660 & 0.02 & 0.02 & 0.02 & 0.887 \\
\hline Residuals & 7 & 0.132 & 0.019 & & & 2.32 & 0.33 & & & 5.37 & 0.77 & & \\
\hline \multicolumn{14}{|l|}{ Active/Inactive Cells } \\
\hline Treatment & 1 & 0.000 & 0.000 & 3.32 & 0.1113 & 0.51 & 0.51 & 0.54 & 0.488 & 0.00 & 0.00 & 7.29 & 0.031 \\
\hline Challenge & 1 & 0.000 & 0.000 & 0.00 & 0.9643 & 0.23 & 0.23 & 0.24 & 0.638 & 0.00 & 0.00 & 0.08 & 0.783 \\
\hline Condition factor & 1 & 0.000 & 0.000 & 0.13 & 0.7311 & 1.10 & 1.10 & 1.17 & 0.316 & 0.00 & 0.00 & 5.84 & 0.046 \\
\hline Treatment*Challenge & 1 & 0.000 & 0.000 & 0.01 & 0.9433 & 0.05 & 0.04 & 0.05 & 0.834 & 0.00 & 0.00 & 0.40 & 0.546 \\
\hline Residuals & 7 & 0.000 & 0.000 & & & 6.63 & 0.95 & & & 0.00 & 0.00 & & \\
\hline
\end{tabular}

and simultaneous immune challenge in $A$. burtoni females. By including naïve males in this comparison we are able to determine the influence of reproduction and female challenge on sexual immune dimorphism. The proportion of adaptive to innate immune cells in the blood of reproducing females was lower than in nonreproducing females and males. Females that had reproduced featured a lower proportion of resting cells in the head kidney than both non-reproducing females and males. The proportion of dividing cells, as well as the dividing to resting cell ratio in the head kidney did not differ between the two female treatments, but between reproducing females and males. A higher ratio of active to inactive adaptive immune cells indicates that reproduction induces the adaptive immune cell proliferation. Vibrio challenge had no effect on cellular immune parameters (Table 4; Fig. 4; Posthoc: Additional file 4: Table S4).

Multivariate analyses reflected that gene expression of the gill tissues was affected by reproduction but not by immune challenge in seven gene groups: "all genes", "innate immune system genes \& complement genes", "adaptive immune system genes", "antimicrobial genes \& oxidative stress genes", "developmental genes" and "metabolism genes". In the following univariate analysis, 15 of 45 genes of interested showed differential expression between the treatments. In more detail, the univariate

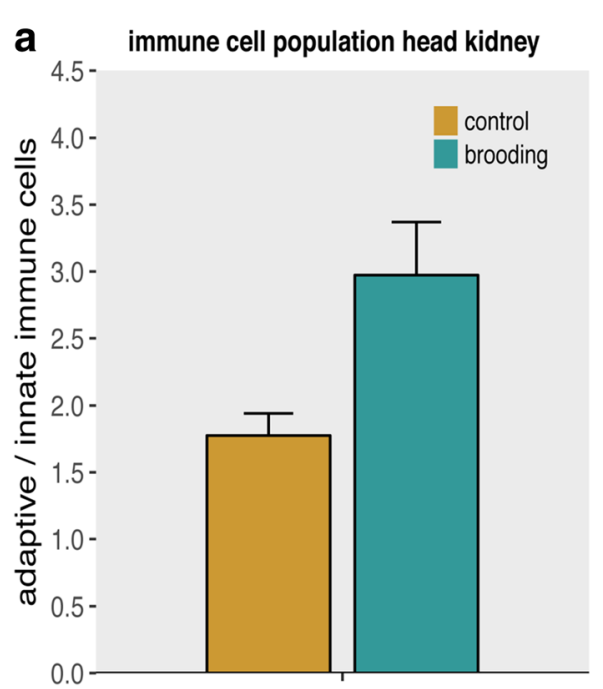

\section{b adaptive immune cell activity head kidney}

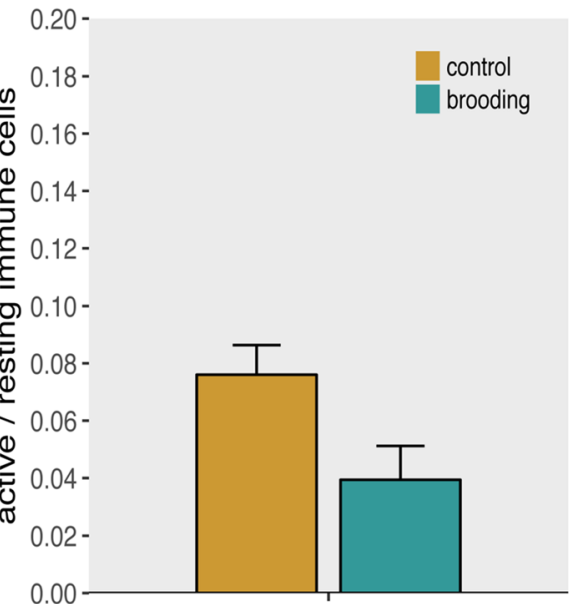

Fig. 2 Immune cell measurements of brooding versus non-brooding females: Bars and error bars show group means with SE. Brown for control females; turquoise for mouthbrooding females. All shown differences are significant $(p<0.05)$. a Proportion of adaptive to innate immune cells of the head kidney. $\mathbf{b}$ Proportion of active to resting adaptive immune cells of the head kidney 


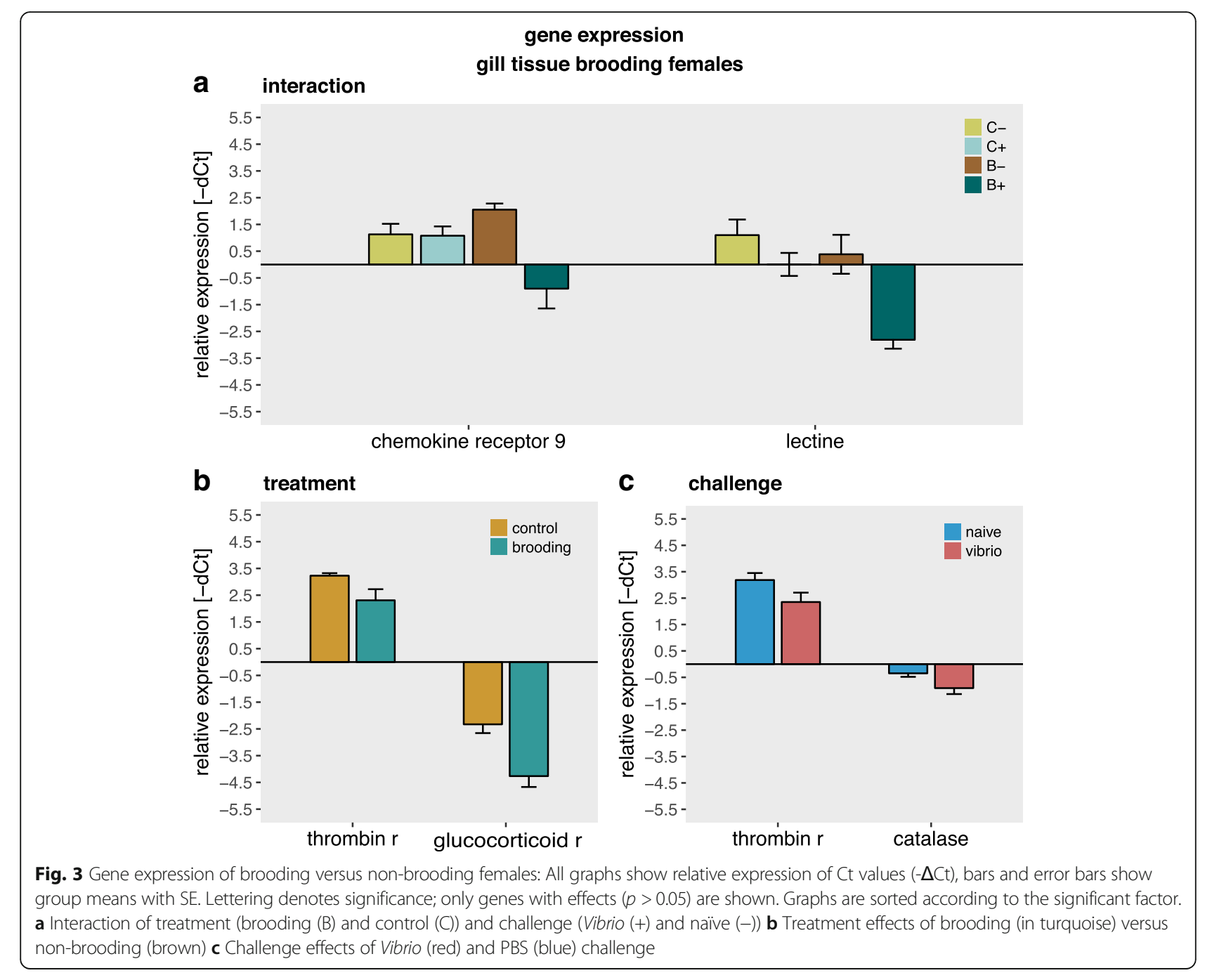

analysis revealed that the expression of latescidin 2, hepcidin, trypsin 1, myogenic regulation factor, opsin 1 and androgen receptor $B$ were downregulated in reproducing females compared to both other treatment groups. Expression of CD81 antigen, involved in cell proliferation and maturation of $\mathrm{T}$ - and B- cells, was upregulated during reproduction. Furthermore, reproducing females had a higher expression of thrombin receptor like I, elongation factor 1 and DNA methyltransferase but a lower expression of the serum amyloid A5 protein gene, than males but not than control females. Males showed a lower expression of $M H C 2 b$, heat shock protein 70 , calreticulin 3 and interleukin 10 than reproducing and non-reproducing females (Multivaraiate: Table 5; Fig. 5 A \& B; Univariate: Additional file 5: Table S5; Tukey HSD: Additional file 6: Table S6).

\section{Impact of immune challenge on mouthbred offspring}

To determine the existence and specificity of trans generational immune priming via buccal mucosa in $A$. burtoni mouthbreed juveniles from either immune challenged
(Vibrio) or naïve (PBS) females where challenged with the same (Vibrio, homologous challenge) or a different (Tenacibacter, heterologous challenge) heat-killed bacteria than the maternal challenge or left naïve in a fully reciprocal design. Both female and juvenile challenge impacted, in mouthbred offspring, the expression of genes involved in the innate immune system \& complement component system, the adaptive immune system, but also epigenetic, sex related and developmental genes (Multivariate: Table 6).

Single gene univariate analyses of those gene groups showed interactive effects of both female and juvenile immune challenge on lysine specific demethylase and Aromatase B. In both genes Vibrio challenged juveniles from Vibrio challenged females ( $\mathrm{fV}: \mathrm{jV})$ had a lower expression than other juveniles ( $\mathrm{fN}: \mathrm{jN}, \mathrm{fN}: \mathrm{jV}, \mathrm{fV}: \mathrm{jN}$ ) except those being challenged with Tenacibaculum (fN:jT \& $\mathrm{fV}: \mathrm{j} \mathrm{T})$. The expression of complement component $1 q$ (C1q) was also lower in Vibrio challenged juveniles from Vibrio challenged females ( $\mathrm{fV}: \mathrm{j} \mathrm{V})$ as compared to all but 
Table 3 Two-way PERMANCOVA results of candidate gene expression from brooding vs. non-brooding females: PERMANCOVA to asses effects of treatment, challenge and their interaction on the relative expression of candidate genes ( $\Delta$ Ct values). A condition factor $\left(\mathrm{K}=\mathrm{W} / \mathrm{TL}^{3}\right)$ was included as covariable. Significant results are marked in bold letters. Results of the univariate posthoc analyses (ANCOVA \& Tukey HSD) can be found in Additional file 2: Table S2 and Additional file 3: Table S3

\begin{tabular}{|c|c|c|c|c|c|c|c|c|c|}
\hline \multirow[t]{2}{*}{ Gene categories } & \multirow{2}{*}{$\begin{array}{l}\text { Model } \\
R^{2}\end{array}$} & \multicolumn{2}{|c|}{ Treatment (T) } & \multicolumn{2}{|c|}{ Challenge $(C)$} & \multicolumn{2}{|l|}{ K } & \multicolumn{2}{|l|}{$T^{*} \mathrm{C}$} \\
\hline & & F Model & $\operatorname{Pr}(>F)$ & F Model & $\operatorname{Pr}(>F)$ & F Model & $\operatorname{Pr}(>F)$ & FModel & $\operatorname{Pr}(>F)$ \\
\hline All genes & 0.62 & 0.93 & 0.507 & 0.93 & 0.499 & 1.28 & 0.261 & 1.11 & 0.326 \\
\hline All IS genes & 0.62 & 0.74 & 0.608 & 0.94 & 0.453 & 1.45 & 0.208 & 1.08 & 0.349 \\
\hline Adaptive IS & 0.67 & 0.57 & 0.619 & 0.48 & 0.708 & 1.68 & 0.216 & 0.76 & 0.489 \\
\hline All innate IS & 0.50 & 1.46 & 0.186 & 2.42 & 0.033 & 1.50 & 0.188 & 1.71 & 0.117 \\
\hline Inflammation & 0.19 & 6.92 & 0.015 & 12.28 & 0.001 & 4.09 & 0.044 & 5.69 & 0.022 \\
\hline Oxidative Stress & 0.73 & 0.34 & 0.725 & 0.27 & 0.767 & 1.07 & 0.358 & 0.92 & 0.403 \\
\hline Various innate IS & 0.59 & 0.22 & 0.796 & 1.97 & 0.178 & 1.25 & 0.303 & 1.33 & 0.280 \\
\hline Antimicrobial Peptides & 0.52 & 2.59 & 0.101 & 1.04 & 0.421 & 1.76 & 0.207 & 1.21 & 0.374 \\
\hline Metabolism genes & 0.70 & 0.88 & 0.431 & 0.87 & 0.463 & 0.52 & 0.666 & 0.69 & 0.555 \\
\hline Epigenetic genes & 0.71 & 1.76 & 0.182 & 0.32 & 0.884 & 0.09 & 0.964 & 0.62 & 0.672 \\
\hline Developmental genes & 0.66 & 0.68 & 0.519 & 0.45 & 0.616 & 0.82 & 0.376 & 1.60 & 0.235 \\
\hline Stress related genes & 0.41 & 4.79 & 0.005 & 2.57 & 0.074 & 1.33 & 0.299 & 1.28 & 0.312 \\
\hline Complement Component & 0.56 & 1.03 & 0.411 & 1.69 & 0.133 & 1.08 & 0.371 & 1.59 & 0.175 \\
\hline Sex related genes & 0.71 & 1.76 & 0.182 & 0.32 & 0.884 & 0.09 & 0.964 & 0.62 & 0.672 \\
\hline Df Residuals / Model & 7 & 1 & & 1 & & 1 & & 1 & \\
\hline Df Total & 11 & & & & & & & & \\
\hline
\end{tabular}

Tenacibaculum challenged juveniles from naïve females (fN:jT) (Fig. 6). Juvenile challenge with Vibrio downregulated the expression of calreticulin 1 (innate immune system) and early growth factor (developmental genes) compared to naïve juveniles (PBS) (Fig. 7a). Effects of female challenge on juvenile gene expression could be shown in 12 of 45 genes of interest. Juveniles of challenged females show a lower expression of chemokine, interleukin
10, ig light chain, tumor necrosis factor $b$, integrin a2, pentraxin 4, myogenic regulation factors, early growth factor, histone lysine methyltransferase, aromatase $B$ and androgen receptor $B$. Only the expression protein $F A M$ $60 \mathrm{~A}$ was upregulated in juveniles from challenged females compared to juveniles from naïve females (Fig. 7b; Univariate: Additional file 7: Table S7; Tukey HSD: Additional file 8: Table S8).

Table 4 Two-way ANCOVA results of cellular immune parameter from males, reproducing and non-reproducing females: Significant $p$ values $(p<0.05)$ are marked in bold letters. Results from Tukey HSD posthoc tests can be found in Additional file 4: Table S4

\begin{tabular}{|c|c|c|c|c|c|c|c|c|c|c|c|c|c|}
\hline & \multirow[b]{2}{*}{ Df } & \multicolumn{4}{|l|}{ Blood } & \multicolumn{4}{|c|}{ Spleen } & \multicolumn{4}{|c|}{ Head Kidney } \\
\hline & & SS & MS & F value & $\operatorname{Pr}(>F)$ & SS & MS & Fvalue & $\operatorname{Pr}(>F)$ & SS & MS & Fvalue & $\operatorname{Pr}(>F)$ \\
\hline \multicolumn{14}{|l|}{ Lymphocyte/Monocyte } \\
\hline Treatment & 2 & 14.50 & 7.25 & 12.25 & $<0.01$ & 1.85 & 0.92 & 2.71 & 0.093 & 1.73 & 0.87 & 1.79 & 0.194 \\
\hline Challenge & 1 & 0.60 & 0.60 & 1.01 & 0.33 & 0.01 & 0.01 & 0.03 & 0.859 & 0.14 & 0.14 & 0.29 & 0.594 \\
\hline Condition factor & 1 & 1.06 & 1.06 & 1.79 & 0.20 & 0.40 & 0.40 & 1.17 & 0.295 & 0.12 & 0.12 & 0.24 & 0.629 \\
\hline Treatment ${ }^{*}$ Challenge & 1 & 0.77 & 0.77 & 1.30 & 0.27 & 0.06 & 0.06 & 0.17 & 0.681 & 0.39 & 0.39 & 0.81 & 0.378 \\
\hline Residuals & 19 & 11.24 & 0.59 & & & 6.12 & 0.34 & & & 9.17 & 0.48 & & \\
\hline \multicolumn{14}{|l|}{ Active/Inactive Cells } \\
\hline Treatment & 2 & 2.08 & 1.04 & 2.11 & 0.15 & 13.05 & 6.53 & 1.82 & 0.188 & 1.48 & 0.74 & 4.65 & 0.023 \\
\hline Challenge & 1 & 0.73 & 0.73 & 1.47 & 0.24 & 10.32 & 10.32 & 2.87 & 0.106 & 0.00 & 0.00 & 0.02 & 0.887 \\
\hline Condition factor & 1 & 1.23 & 1.23 & 2.50 & 0.13 & 4.62 & 4.62 & 1.29 & 0.270 & 0.48 & 0.48 & 2.99 & 0.100 \\
\hline Treatment ${ }^{*}$ Challenge & 1 & 0.37 & 0.37 & 0.75 & 0.40 & 1.12 & 1.12 & 0.31 & 0.582 & 0.05 & 0.05 & 0.33 & 0.570 \\
\hline Residuals & 19 & 8.38 & 0.49 & & & 71.78 & 3.59 & & & 3.02 & 0.16 & & \\
\hline
\end{tabular}



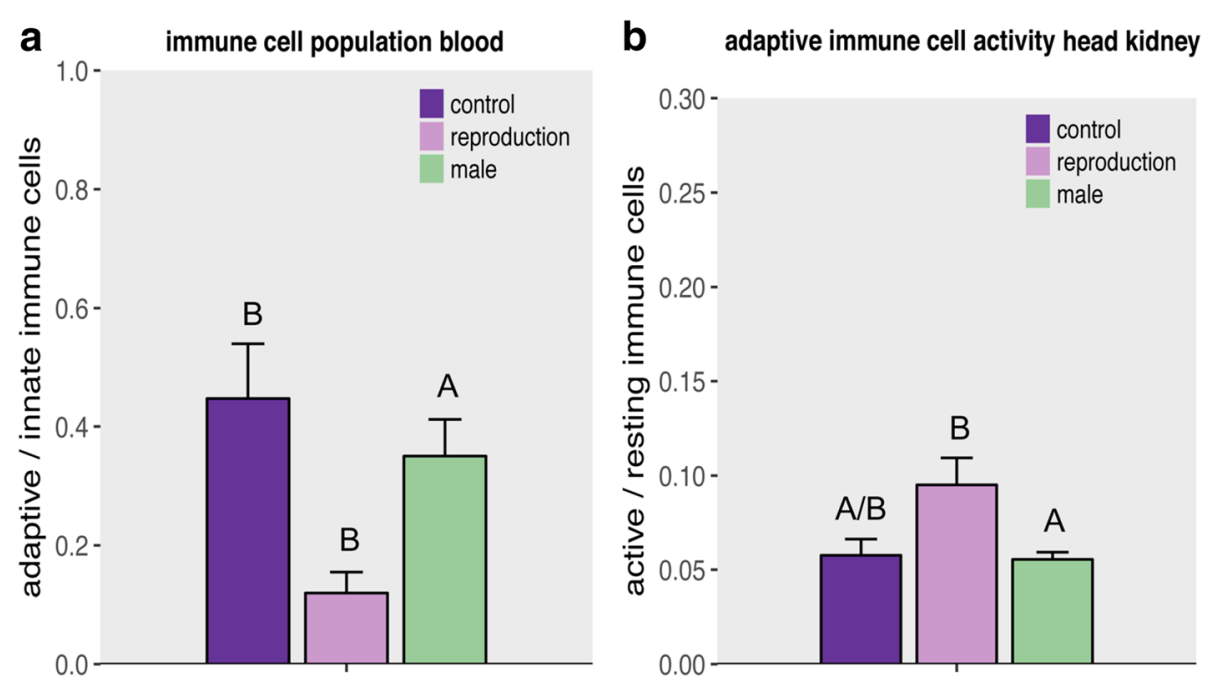

Fig. 4 Immune cell measurements of males and reproducing versus non-reproducing females: Both graphs show bars and error bars with group means and SE. Lettering denotes significant differences. Females are shown in violet (dark for control, and light for reproduction) and males are shown in green. a Proportion of adaptive to innate immune cells of the blood. $\mathbf{b}$ Proportion of active to resting adaptive immune cells in the head kidney

\section{Discussion}

While, to our knowledge, previous studies on TGIP have exclusively focused on either the parental costs or the offspring benefits $[8,18,31,67,74,79]$, this study aimed to illuminate the impact and the interaction of parental investment on the parental and the offspring immune system. The integration of both sides, parents and offspring, allows drawing conclusions about trade-offs in reproduction and immune defense. By enlightening consequences on both the parental and the offspring

Table 5 Two-way PERMANCOVA results of candidate gene expression from males, reproducing and non-reproducing females: PERMANCOVA to asses effects of treatment, challenge and their interaction on the relative expression of candidate genes ( $\Delta \mathrm{Ct}$ values). A condition factor $\left(\mathrm{K}=\mathrm{W} / \mathrm{TL}^{3}\right)$ was included as covariable. Significant results are marked in bold letters. Results of the univariate posthoc analysis (ANCOVA \& Tukey HSD) can be found in Additional file 5: Table S5 and Additional file 6: Table S6

\begin{tabular}{|c|c|c|c|c|c|c|c|c|c|}
\hline \multicolumn{10}{|l|}{ Permancova } \\
\hline \multirow[t]{2}{*}{ Gene categories } & \multirow{2}{*}{$\begin{array}{l}\text { Model } \\
R 2\end{array}$} & \multicolumn{2}{|c|}{ Treatment (T) } & \multicolumn{2}{|c|}{ Challenge (C) } & \multicolumn{2}{|l|}{ K } & \multicolumn{2}{|l|}{$T^{*} \mathrm{C}$} \\
\hline & & F. Model & $\operatorname{Pr}(>F)$ & F. Model & $\operatorname{Pr}(>F)$ & F. Model & $\operatorname{Pr}(>F)$ & F. Model & $\operatorname{Pr}(>F)$ \\
\hline All genes & 0.64 & 3.23 & 0.002 & 0.76 & 0.649 & 0.62 & 0.755 & 1.05 & 0.351 \\
\hline All IS genes & 0.62 & 3.37 & 0.003 & 0.77 & 0.633 & 0.81 & 0.565 & 1.29 & 0.243 \\
\hline Adaptive IS & 0.58 & 3.48 & 0.001 & 0.85 & 0.534 & 1.39 & 0.229 & 2.18 & 0.062 \\
\hline All innate IS & 0.64 & 3.46 & 0.003 & 0.71 & 0.685 & 0.46 & 0.852 & 0.78 & 0.581 \\
\hline Inflammation & 0.74 & 1.87 & 0.105 & 1.01 & 0.404 & 0.10 & 0.971 & 0.03 & 0.999 \\
\hline Oxidative Stress & 0.66 & 2.92 & 0.031 & 0.77 & 0.480 & 0.34 & 0.736 & 0.88 & 0.423 \\
\hline Various innate IS & 0.61 & 4.46 & 0.003 & 0.51 & 0.708 & 0.44 & 0.675 & 0.50 & 0.651 \\
\hline Antimicrobial Peptides & 0.49 & 6.58 & 0.011 & 0.69 & 0.535 & 1.62 & 0.205 & 1.56 & 0.218 \\
\hline Metabolism genes & 0.69 & 3.49 & 0.049 & 0.13 & 0.939 & 0.03 & 0.941 & 0.19 & 0.741 \\
\hline Epigenetic genes & 0.70 & 0.93 & 0.493 & 2.16 & 0.063 & 0.22 & 0.918 & 0.88 & 0.464 \\
\hline Developmental genes & 0.58 & 5.41 & 0.006 & 0.10 & 0.997 & 0.06 & 0.981 & 1.49 & 0.230 \\
\hline Stress related genes & 0.75 & 1.19 & 0.331 & 0.98 & 0.398 & 0.89 & 0.457 & 0.36 & 0.811 \\
\hline Complement Component & 0.65 & 3.31 & 0.001 & 0.72 & 0.663 & 0.48 & 0.840 & 0.79 & 0.559 \\
\hline Sex related genes & 0.55 & 4.88 & 0.003 & 1.55 & 0.223 & 0.19 & 0.885 & 0.98 & 0.384 \\
\hline Df Residuals / Model & 17 & 2 & & 2 & & 1 & & 1 & \\
\hline Df Total & 23 & & & & & & & & \\
\hline
\end{tabular}



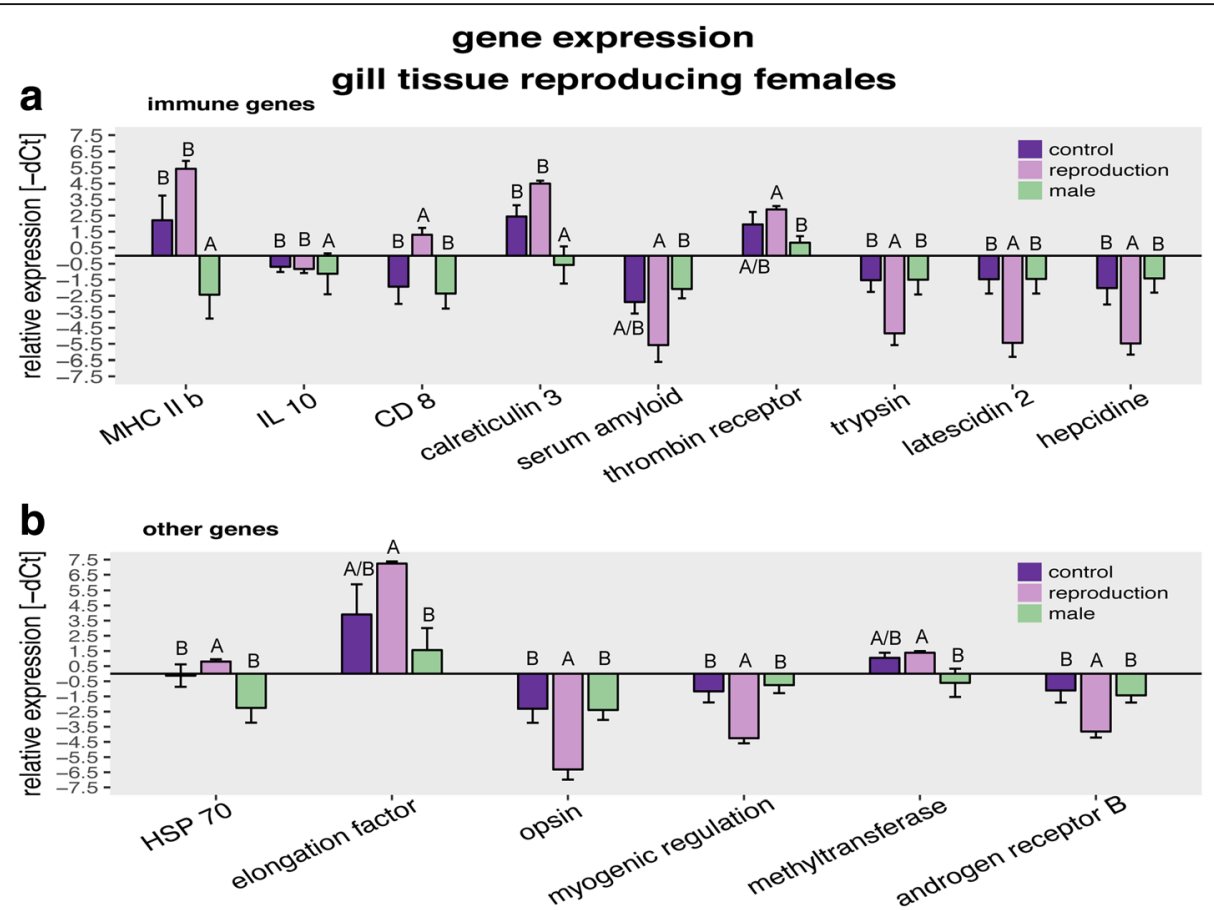

Fig. 5 Gene expression of males and reproducing versus non-reproducing females: All graphs show relative expression of $\mathrm{Ct}$ values (- $\Delta \mathrm{Ct}$ ), bars and error bars show group means with SE. Lettering denotes significance; only significantly different genes are shown. Females in violet (dark for control, and light for reproduction) and males in green. Graphs are sorted according to candidate gene function. a Genes of the immune system. b Genes from other gene groups

side, we can add to the understanding of costs and benefits of parental investment, immune response and the evolution of mouthbrooding in particular.

\section{Cost of mouthbrooding on Astatotilapia burtoni female immune defense}

The first part of this study was designed to assess the costs associated with mouthbrooding and reproduction and their effect on the capability of mounting an immune response in adults. To this end, females of $A$. burtoni being challenged with heat-killed Vibrio bacteria or left naïve (challenge with $\mathrm{PBS}$ ) were either allowed to complete mouth brooding (I.) or were stripped off their brood after reproduction (II.). Both treatment groups were then compared to non-reproducing individuals.

Mouthbrooding females showed a lowered activity of adaptive immune cells and their ratio of adaptive to innate immune cells was higher in the head kidney (Fig. 2); inflammation genes were downregulated, whereas stress related genes were upregulated (Fig. 3). Two genes, chemokine receptor 9 (CCR9) and lectin were downregulated in females that had to pay the dual costs of mouthbrooding and activation of the immune system upon immune challenge. CCR9 is involved in T-cell maturation and migration [94] and upregulated after Vibrio anguillarum infection in sea bass [30]. Lectin enhances the antibacterial and antifungal properties of mucus [54]. A downregulation of CCR9 and lectin upon mouthbrooding in combination with immune challenge indicates a resource-allocation trade-off between parental care and the immune system. Thrombin receptor $(T R)$ that is closely associated with the lectin activated complement pathway was downregulated during brooding and upon an immune challenge (Fig. 3). In previous studies with rock bream, higher $T R$ expression has been found upon immune challenge with Vibrio [17].

Brooding and immune challenge may induce different stress responses. Moutbrooding led to a downregulation of glucocorticoid receptor. A correlation between reduction of glucocorticoid receptors and increased corticosterone secretion was identified in prenatally challenged rats [69]. Downregulation of glucocorticoid receptor could thus indicate higher cortisol levels. To our knowledge, cortisol levels during mouthbrooding has not yet been measured in cichlids. In Oreochromis mosambicus, a mouth brooding tilapine cichlid, treatment with cortisol decreased oozyte size and parental growth, indicating a trade-off between reproduction and somatic maintenance induced by cortisol [28]. Despite the fact that evidence of elevated stress in the parental phase of cichlids exists [43] concluding from reduced glucocorticoid receptor expression in the gills to higher general stress levels could be misleading. Nevertheless, glucocorticoid receptors are known to be involved in the anti-inflammatory response $[16,86]$. 
Table 6 nested MANOVA results of gene expression analysis of mouthbred juveniles: nested MANOVA to asses effects of maternal challenge, juvenile challenge and their interaction on the relative expression of candidate genes ( $\Delta \mathrm{Ct}$ values) in mouthbred juveniles. Female challenge was nested in family. Significant results are marked in bold letters. Results of the univariate posthoc analysis (ANCOVA \& Tukey HSD) can be found in Additional file 7: Table S7 and Additional file 8: Table S8

\begin{tabular}{|c|c|c|c|c|c|c|c|c|c|c|c|c|c|c|c|c|}
\hline \multicolumn{2}{|l|}{ nested MANOVA } & \multicolumn{5}{|c|}{ All genes } & \multicolumn{5}{|c|}{ All immune genes } & \multicolumn{5}{|c|}{ Adaptive genes } \\
\hline Factors & DF & Pillai & $\mathrm{F}$ & n Df & d Df & $\operatorname{Pr}(>F)$ & Pillai & $\mathrm{F}$ & n Df & d Df & $\operatorname{Pr}(>F)$ & Pillai & F & n Df & $d$ Df & $\operatorname{Pr}(>F)$ \\
\hline Juvenile Challenge (jC) & 2 & 1.98 & 5.35 & 90 & 4 & 0.055 & 1.16 & 1.11 & 52 & 42 & 0.362 & 0.37 & 0.97 & 18 & 76 & 0.497 \\
\hline Maternal Challenge (mC) & 1 & 1.00 & 2972.31 & 45 & 1 & 0.015 & 0.86 & 4.67 & 26 & 20 & $<0.001$ & 0.28 & 1.60 & 9 & 37 & 0.152 \\
\hline $\mathrm{jC} * \mathrm{mC}$ & 2 & 1.92 & 1.03 & 90 & 4 & 0.571 & 1.20 & 1.21 & 52 & 42 & 0.263 & 0.31 & 0.77 & 18 & 76 & 0.726 \\
\hline $\mathrm{mC}$ in family & 4 & 3.95 & 6.87 & 180 & 16 & 0.000 & 2.85 & 2.20 & 104 & 92 & $<0.001$ & 1.24 & 2.01 & 36 & 160 & 0.002 \\
\hline \multirow[t]{2}{*}{ Residuals } & 45 & & & & & & & & & & & & & & & \\
\hline & & \multicolumn{5}{|c|}{ All innate IS } & \multicolumn{5}{|c|}{ Inflammation } & \multicolumn{5}{|c|}{ Oxidative Stress } \\
\hline Factors & DF & Pillai & $\mathrm{F}$ & n Df & $d$ Df & $\operatorname{Pr}(>F)$ & Pillai & $\mathrm{F}$ & n Df & $d D f$ & $\operatorname{Pr}(>F)$ & Pillai & $\mathrm{F}$ & n Df & $d$ Df & $\operatorname{Pr}(>F)$ \\
\hline Juvenile Challenge (jC) & 2 & 0.75 & 1.27 & 30 & 64 & 0.211 & 0.34 & 1.72 & 10 & 84 & 0.089 & 0.19 & 1.50 & 6 & 88 & 0.188 \\
\hline Maternal Challenge (mC) & 1 & 0.80 & 8.45 & 15 & 31 & $<0.001$ & 0.28 & 3.25 & 5 & 41 & 0.015 & 0.05 & 0.68 & 3 & 43 & 0.568 \\
\hline$j C * m C$ & 2 & 0.58 & 0.88 & 30 & 64 & 0.643 & 0.25 & 1.18 & 10 & 84 & 0.318 & 0.13 & 1.05 & 6 & 88 & 0.398 \\
\hline $\mathrm{mC}$ in family & 4 & 1.90 & 2.06 & 60 & 136 & $<0.001$ & 0.50 & 1.26 & 20 & 176 & 0.212 & 0.39 & 1.66 & 12 & 135 & 0.082 \\
\hline \multirow[t]{2}{*}{ Residuals } & 45 & & & & & & & & & & & & & & & \\
\hline & & \multicolumn{5}{|c|}{ Various innate IS } & \multicolumn{5}{|c|}{ Antimicrobial Peptides } & \multicolumn{5}{|c|}{ Complement Components } \\
\hline Factors & DF & Pillai & $\mathrm{F}$ & n Df & $d$ Df & $\operatorname{Pr}(>\mathrm{F})$ & Pillai & $\mathrm{F}$ & n Df & d Df & $\operatorname{Pr}(>F)$ & Pillai & $\mathrm{F}$ & $n$ Df & d Df & $\operatorname{Pr}(>F)$ \\
\hline Juvenile Challenge (jC) & 2 & 0.29 & 1.84 & 8 & 86 & 0.080 & 0.22 & 2.84 & 4 & 90 & 0.029 & 0.77012 & 1.105 & 34 & 60 & 0.361 \\
\hline Maternal Challenge (mC) & 1 & 0.15 & 1.88 & 4 & 42 & 0.132 & 0.06 & 1.30 & 2 & 44 & 0.283 & 0.80387 & 6.992 & 17 & 29 & $<0.001$ \\
\hline $\mathrm{jC} * \mathrm{mC}$ & 2 & 0.14 & 0.84 & 8 & 86 & 0.571 & 0.05 & 0.59 & 4 & 90 & 0.667 & 0.64951 & 0.8487 & 34 & 60 & 0.693 \\
\hline $\mathrm{mC}$ in family & 4 & 0.61 & 2.04 & 16 & 180 & 0.013 & 0.25 & 1.58 & 8 & 90 & 0.143 & 2.19249 & 2.2833 & 68 & 128 & $<0.001$ \\
\hline \multirow[t]{2}{*}{ Residuals } & 45 & & & & & & & & & & & & & & & \\
\hline & & \multicolumn{5}{|c|}{ Epigenetic genes } & \multicolumn{5}{|c|}{ Developmental genes } & \multicolumn{5}{|c|}{ Stress related genes } \\
\hline Factors & DF & Pillai & $\mathrm{F}$ & n Df & $d$ Df & $\operatorname{Pr}(>F)$ & Pillai & $\mathrm{F}$ & $n$ Df & $d$ Df & $\operatorname{Pr}(>F)$ & Pillai & $\mathrm{F}$ & n Df & d Df & $\operatorname{Pr}(>F)$ \\
\hline Juvenile Challenge $(\mathrm{jC})$ & 2 & 0.25 & 1.19 & 10 & 84 & 0.306 & 0.23 & 1.40 & 8 & 86 & 0.208 & 0.28 & 1.76 & 8 & 86 & 0.097 \\
\hline Maternal Challenge (mC) & 1 & 0.31 & 3.73 & 5 & 41 & 0.007 & 0.16 & 1.93 & 4 & 42 & 0.122 & 0.01 & 0.13 & 4 & 42 & 0.972 \\
\hline $\mathrm{jC} * \mathrm{mC}$ & 2 & 0.37 & 1.90 & 10 & 84 & 0.056 & 0.21 & 1.27 & 8 & 86 & 0.268 & 0.19 & 1.10 & 8 & 86 & 0.374 \\
\hline $\mathrm{mC}$ in family & 4 & 0.70 & 1.88 & 20 & 176 & 0.017 & 0.54 & 1.74 & 16 & 180 & 0.042 & 0.29 & 0.89 & 16 & 180 & 0.586 \\
\hline \multirow[t]{2}{*}{ Residuals } & 45 & & & & & & & & & & & & & & & \\
\hline & & \multicolumn{5}{|c|}{ Metabolism genes } & \multicolumn{5}{|c|}{ Sex related genes } & & & & & \\
\hline Factors & DF & Pillai & $\mathrm{F}$ & n Df & $d$ Df & $\operatorname{Pr}(>F)$ & Pillai & $\mathrm{F}$ & n Df & $d$ Df & $\operatorname{Pr}(>\mathrm{F})$ & & & & & \\
\hline Juvenile Challenge (jC) & 2 & 0.13 & 1.02 & 6 & 88 & 0.418 & 0.29179 & 2.5053 & 6 & 88 & 0.027622 & & & & & \\
\hline Maternal Challenge (mC) & 1 & 0.17 & 2.91 & 3 & 43 & 0.045 & 0.2595 & 5.0231 & 3 & 43 & 0.004501 & & & & & \\
\hline $\mathrm{jC} * \mathrm{mC}$ & 2 & 0.06 & 0.49 & 6 & 88 & 0.816 & 0.12935 & 1.0142 & 6 & 88 & 0.421418 & & & & & \\
\hline $\mathrm{mC}$ in family & 4 & 0.32 & 1.35 & 12 & 135 & 0.196 & 0.20872 & 0.8412 & 12 & 135 & 0.608014 & & & & & \\
\hline Residuals & 45 & & & & & & & & & & & & & & & \\
\hline
\end{tabular}

Immune challenge led to a downregulation of catalase, an oxidative stress related gene. Low catalase levels may indicate lower antioxidant capacities, which could raise additional costs for the female, as brooding and reproduction were previously shown to elevate oxidative stress and lower the antioxidant capacities of the immune system in many organisms $[2,61]$.
In summary, our results suggest that parental care provided during mouthbrooding may be traded off with investment into the immune system. Mouthbrooding decreased the expression of glucocorticoid receptor thus possibly inducing the level of the stress hormone cortisol. Immune challenge elevated the extent of oxidative stress as reflected by a lower expression of catalase. Both, 


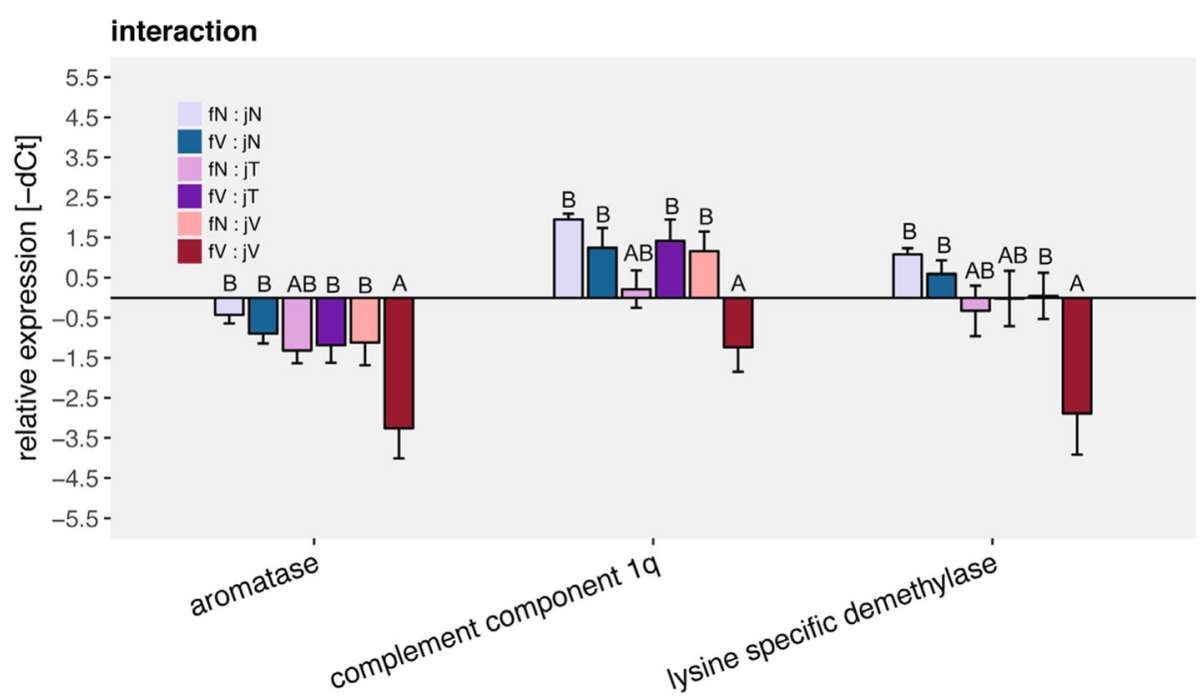

Fig. 6 Gene expression of mouthbred juveniles; maternal challenge $x$ juvenile challenge: All graphs show relative expression of $C t$ values $(-\Delta C t)$, bars and error bars show group means with SE. Lettering denotes significance; only significantly different genes are depicted. Abbreviation consist of female challenge and juvenile challenge (maternal challenge: juvenile challenge): $\mathrm{fN}$ for naïve maternal challenge, $\mathrm{fV}$ for maternal Vibrio challenge, $\mathrm{jN}$ for naïve juvenile challenge, $\mathrm{J}$ for juvenile Tenacibaculum challenge, $\mathrm{j}$ for juvenile Vibrio challenge

glucocorticoid receptor and catalase activity might additionally modulate the female immune system $[37,97]$.

\section{Cost of reproduction and influence on sexual immune dimorphism}

We hypothesized a trade-off between investment in immune defense and reproduction in female mouthbrooding cichlid fish in the form of immune suppression during reproduction, as has previously been demonstrated in various vertebrate species $[12,21,58,63,81]$. To this end, we compared immune gene expression and cellular immune parameters of reproducing and non-reproducing females after either being challenged with $V$. anguillarum or left naïve. We indeed observed a reduced proportion of adaptive immune cells in the blood of reproducing females, irrespective of whether or not an immune challenge had taken place (Fig. 4), accompanied by the downregulation of genes of the innate immune system (trypsin, latescidin 2, hepcidin), some metabolism genes (opsin 1, myogenic regulation factor) and a hormone receptor (androgen receptor $B$ ) compared to non reproducing females (Fig. 5). However, we also found that the stress responsive heat shock protein 70 (HSP70) and the transmembrane protein CD81 (CD81) were upregulated in reproducing females. In the case of mouthbrooding cichlid fish, HSP70 - on the basis of its protein chaperoning functions $[19,57,70]$ - might be responsible for the transport of proteins into the buccal mucus to support brooding. In mouse it has been shown that HSP70 plays an important role in the maturation of dendritic cells and stimulates cytotoxic T-cell maturation via MHC class I [57]. Upregulation of HSP 70 might possibly be triggered by a general physiological stress response, such as reproduction. CD81 is a transmembrane protein, in complex with other responsible for both $\mathrm{B}$ - and T-cell maturation and proliferation (reviewed in Lewi et al. [50]). In mice it has been found to be expressed on MHC I molecules [15]. Due to the very diverse function of CD81, an upregulation can have several effects, depending on tissue and costimulatory molecules [50].

Regardless of their reproductive state, females showed a higher expression of adaptive immune genes, when compared to males (Fig. 5). This suggests that also haplochromine cichlid fishes exhibit a sexual immune dimorphism, with females having an elevated adaptive immunological baseline activity prolonging their lifespan to reach a similar reproductive output as males [71]. On the other hand, our data are in contrast to the resource allocation hypothesis, as we found that reproducing females have a higher adaptive immune cell activity (Fig. 4) and a higher expression of innate, developmental and epigenetic genes combined with a lower expression of acute phase protein (Serum Amyloid A5 (SAA)) than males but not than non-reproducing 'control' females. This contradicts previous results, where differences between reproductive and non-reproductive females were observed $[12,21,25$, $63]$. One explanation for the induced adaptive immune response at reproduction could be that females invest into offspring immunity via TGIP, e.g. via the aggregation of proteins advantageous for the offspring in the newly formed egg [100]. The synthesis of such proteins could induce gene expression in the female. An interactive effect of reproduction and challenge on female gene expression, showing a clear pattern of TGIP or resource allocation trade-off, was not observed in the gill tissue. 


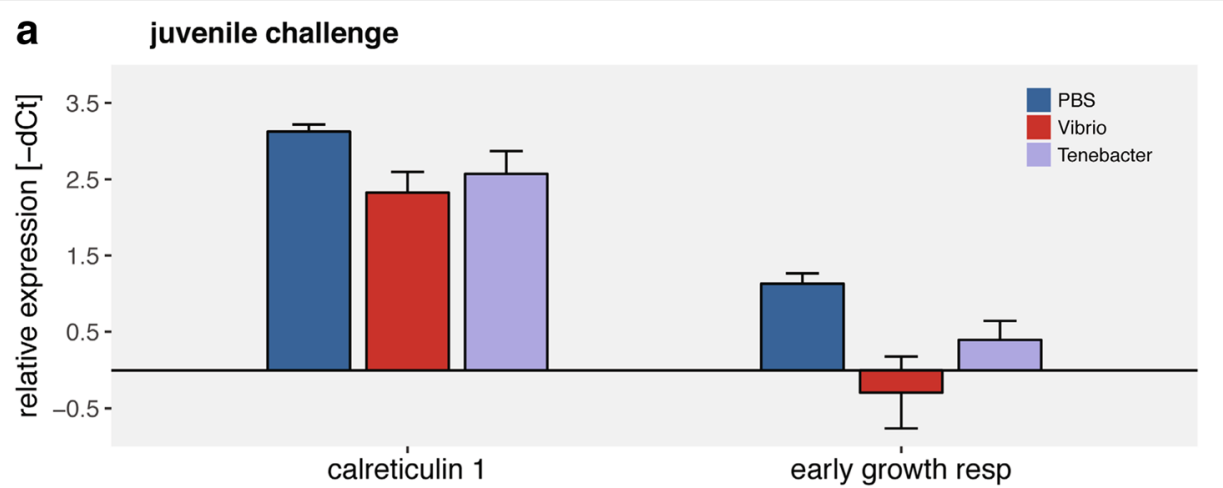

b female challenge

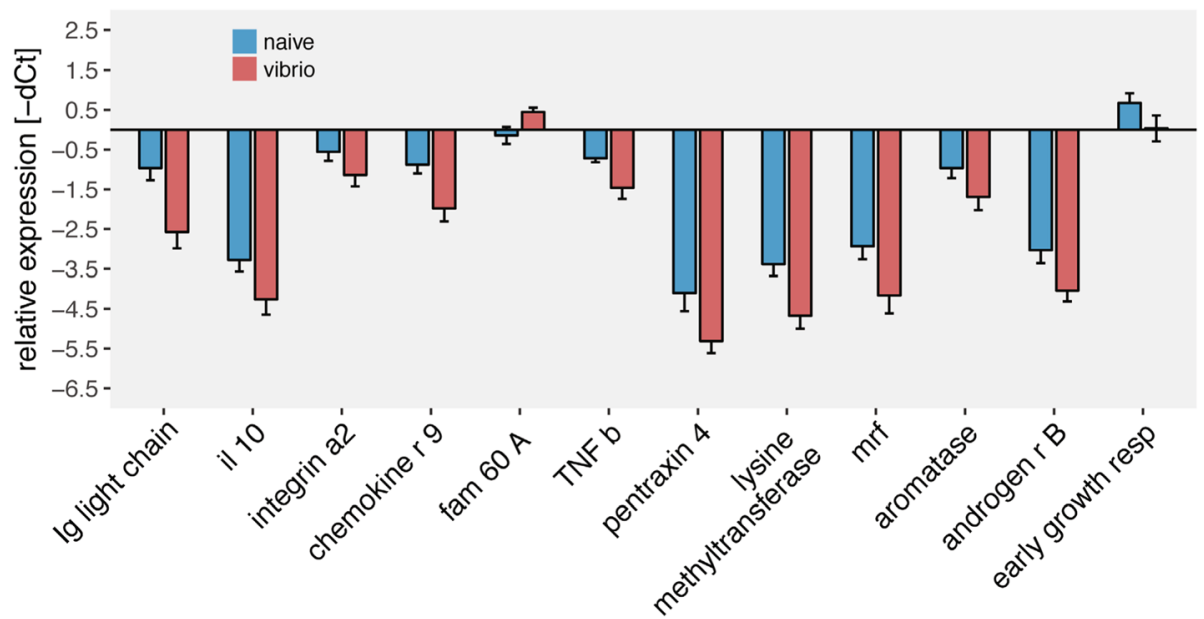

Fig. 7 Gene expression of mouthbred juveniles; maternal challenge and juvenile challenge: All graphs show relative expression of Ct values $(-\Delta C t)$, bars and error bars depict group means with SE. Graphs are sorted according to significant factors. Lettering denotes significance; only genes with effects are shown. a Genes affected by juvenile challenge. Blue for naïve (PBS), red for Vibrio and violet for Tenacibacter. b Genes affected by maternal challenge. Light blue; naïve mothers (PBS) and light red; Vibrio challenged mothers

Both, mouthbrooding and reproduction independently suppress parts of the female immune system and enhance stress responses in female Astatotilapia burtoni. Additionally, reproduction accentuates the present sexual immune dimorphism. Due to experimental constraints, we were not able to directly compare immune competence between reproducing and mouthbrooding females. Nevertheless, it seems that differential limitations are opposed on the female immune system during reproduction and mouthbrooding. Reproduction influenced mainly genes involved in metabolism and general innate immune system genes possibly due to extended energy expenditure during oogenesis. Mouthbrooding seems to induce stress reflected in a downregulation of inflammation responses and an increase of oxidative stress in the females. Additionally, mouthbrooding and reproduction differentially affect both the proportion and the activity of adaptive immune cells. These differences possibly arise due to differential allocation of resources in egg production and provisioning of larvae.

\section{Impact of immune challenge on mouthbred offspring}

We aimed to address the transfer of immune components via the buccal mucosa as a potential additional immunological boost of offspring early life stages to the transfer via egg, and the specificity of such transferred immunological information. As opposed to our initial aim, we could not differentiate among transfer of maternal immunity via the eggs and via buccal mucosa, as mortality in the artificially bred offspring was too high. The much higher rate of survival in the treatment group where parental investment was provided implies that mouthbrooding is beneficial. We thus only discuss the differences in gene expression after homologous or heterologous immune challenge of offspring being mouthbred by Vibrio challenged or naïve females. Indications for such specific trans-generational immune priming would be identified via the interaction of female and juvenile challenge effects (Fig. 6). In contrast to our expectations, the lysine specific demethylase (LSDM), the complement component $1 q(C 1 q)$ and 
aromatase (Arom B) were downregulated in juveniles treated with a challenge homologous to their mothers compared to the other treatments. LSDM is important for cell proliferation, embryonic development and transcription activity of T cells [52, 64]. C1q interacts with pattern recognition, inflammation and activation of the adaptive immune system [27] and is suggested to play a role in organ development [96]. Aromatase is responsible for the conversion of testosterone to estradiol and, if downregulated induces testosterone concentration in the organism, which potentially can be immune suppressive $[55,58]$. This may indicate that females, which have the dual cost of inducing their immune system upon an immune challenge and providing parental investment via mouthbrooding, are limited in the resources they can invest into the eggs and larvae. This would be in line with the hypothesized resourceallocation trade-off between reproduction and the immune system and potentially imply that offspring from challenged females might be of lower quality than offspring of naïve females, reflected in their disability of upregulating gene expression upon an immune challenge. Alternatively, if females provide all necessary compounds via the egg or the buccal mucosa to the offspring, there may simply not be the need for offspring to upregulate those genes due to adaptive maternal effects. Offspring challenged with Vibrio, irrespective of the maternal challenge, had a lower expression of the early growth receptor (egr1), important in cell proliferation and embryogenesis of the gill vessel system [99]. Vibrio challenged offspring also had a lower expression of calreticulin 1 (calret 1 ), responsible for protein chaperoning as response of oxidative stress [53] (Fig. 7). These results are in contrast to the current literature, as in this juvenile developmental stage and under infection both genes were shown to be upregulated [53, 99]. Downregulation of both genes could be a sign for lower developmental potential of the juveniles faced with a Vibrio challenge. FAM60A was upregulated in the offspring from the treatment group in which the mothers were immune challenged (Fig. 7). FAM60A regulates the expression of the TGF beta signaling pathway, increases cell migration and is, within a histone acetylation complex, responsible for elevated cell division during stress $[62,83]$. Both the effects of the juvenile challenge and the maternal challenge on the offspring gene expression could be a sign of induced stress in the offspring from challenged mothers, previously shown to suffering elevated stress levels. Higher levels of stress hormones possibly suppress the offspring immune competence [51] and may even impede embryonic development. Due to the candidate gene approach taken, the probability is high that key genes responsible for both TGIP and specific defenses upon bacterial exposure were not captured in this study. With the limited number of genes assessed, we could not detect an adaptive pattern of trans-generational immune priming, however an impact of maternal immunological and stress experience. In contrast to our expectations, homologous maternal and offspring immunological exposure did not induce but rather downregulate the expression of genes involved in the complement system and in epigenetic regulation. This either implies that previous specific maternal immune challenge boosted the immunological response in the offspring such, that juveniles are not in need to induce the expression of several immune genes. Alternatively, maternal immune challenge impaired a specific activation of immune response, possibly due to a maternal resource allocation trade-off between reproduction and the maternal immune system. This implies that trans-generational phenotypic plasticity may be limited if concurrently to the reproductive event a stressor is met in the parental generation.

\section{Conclusion}

Both the onset of reproduction and the long-lasting mouthbrooding are stressful for female cichlid fish due to the costs involved in the extreme parental investment provided. Shortly after fertilization females of the reproduction treatment reduce their innate immune response, metabolism, and hormone production, whilst genes involved in immune regulations and stress responses (e.g. HSP70, CD81) become upregulated. The possible preparation of the buccal mucosa for later brooding at this early stage of reproduction might be reflected in an induced activity of adaptive immune cells, and the enhanced expression of developmental and epigenetic genes, in particular in comparison to the lower immunological activity of males. However, when faced with an immune challenge, the investment into the buccal mucosa might be impeded due to high energy demands of the immune system, resulting in a resource allocation trade-off between reproduction and the immune system and potentially even a lower quality of offspring. At the end of mouthbrooding, when parental investment is ceased, females seem dissipated, which is reflected in their reduced expression of inflammation genes and an induced stress gene expression. The strong effect of maternal challenge on juveniles suggests the existence of maternal effects; nevertheless, no signs for adaptive trans-generational immune priming were detected. As a consequence, mothers exposed to an immune challenge that simultaneously fulfilled the task of brooding produced offspring with lower immune gene expression, implying a limited transfer of resources from stressed mothers towards their offspring. Parental investment boosts offspring survival. However, 
the energy requirements for parental investment are high and in a situation where other life-history traits may demand a reallocation of resources, the limits of energy availability seems reached. This may impede both mothers and offspring simultaneously, resulting in physiological stress on the maternal side and a reduced ability for activation of gene expression on the offspring side.

\section{Additional files}

Additional file 1: Table S1. List of all primers used for candidate gene expression: Table depicts gene names, functions, fwd and rev sequences and references for those, which have not been designed by the authors. (PDF $43 \mathrm{~kb}$ )

Additional file 2: Table S2. ANCOVA on candidate genes from brooding versus non-brooding females: Univariate analysis following significant gene groups in multivariate PERMANCOVA. Significant $p$-Values are marked with asterisk (code: $p$-Value $>0.001{ }^{* *} ;>0.01{ }^{*} ;>0.01 *$. . -values marked additionally in bold are in agreement with the results from the multivariate analysis. (PDF $57 \mathrm{~kb}$ )

Additional file 3: Table S3. Tukey HSD test on candidate genes from brooding versus non-brooding females: Posthoc test following significant results from two-way ANCOVA. P-values marked in bold are in agreement with the results from the univariate analysis. (PDF $32 \mathrm{~kb}$ )

Additional file 4: Table S4. Tukey HSD test on cellular immune parameter from males, reproducing and non-reproducing females: Posthoc test following significant results from two-way ANCOVA. P-values marked in bold are in agreement with the results from the univariate analysis. (PDF $32 \mathrm{~kb}$ )

Additional file 5: Table S5. ANCOVA on candidate genes from males, reproducing and non-reproducing females: Univariate analysis following significant gene groups in multivariate PERMANCOVA. Sigificant $p$-Values are marked with asterisk (code: $p$-Value $>0.001 * * *>0.01 * * ;>0.01 *$ ). $\mathrm{P}$-values marked additionally in bold are in agreement with the results from the multivariate analysis. (PDF $69 \mathrm{~kb}$ )

Additional file 6: Table S6. Tukey HSD test on candidate genes from males, reproducing and non-reproducing females: Posthoc test following significant results from two-way ANCOVA. P-values marked in bold are in agreement with the results from the univariate analysis. (PDF $41 \mathrm{~kb}$ )

Additional file 7: Table S7. nested ANOVA on candidate genes from mouthbred juveniles: Univariate analysis following significant gene groups in multivariate nested MANOVA. Significant $p$-Values are marked with asterisk (code: $p$-Value $>0.001{ }^{* *} ;>0.01{ }^{* *} ;>0.01 *$ ). P-values marked additionally in bold are in agreement with the results from the multivariate analysis. (PDF $74 \mathrm{~kb}$ )

Additional file 8: Table S8. Tukey HSD test on candidate genes from mouthbred juveniles: Posthoc test following significant results from two-way ANCOVA. P-values marked additionally in bold are in agreement with the results from the univariate analysis. (PDF $51 \mathrm{~kb}$ )

\section{Abbreviations}

B: Brooding treatment; C: Control treatment; FSC: Forward Scatter; K: condition factor; L: lymphocyte; M: Monocyte; MS222: Ethyl 3-aminobenzoate methanesulfonate; PBS: phosphate buffered saline; R: Reproduction treatment; R: Resting phase; S: Dividing phase; SL: standard length; SSC: Side Scatter; T: Tenebacilum treatment; TGIP: trans-generational immune priming; TL: total length; V: Vibrio treatment; VIE: Visible Elastomer Tags; W: weight

\section{Acknowledgments}

We thank M. Grimm and F. Wendt for their help and innovative solutions for keeping and breeding fish. M. Poirier and D. Gill for their expertise and patience during laboratory work. A. Beemelmanns for her knowledge in statistics and A. Franke for discussions about statistics.

\section{Funding}

This study was funded by a research grant from the German Research Foundation (RO 4628/1-1) and the Volkswagen Foundation (IW 84763) to OR. WS received funding by the European Research Council (ERC, Starting Grant "INTERGENADAPT" and Consolidator Grant "CICHLID_X"), and the Swiss National Science Foundation (SNF, grants 3100A0 138,224 and 3100A0 156,405). The funders had no role in study design, data collection and analysis, decision to publish, or preparation of the manuscript.

\section{Availability of data and materials}

All data are archived and accessible at PANGAEA https://doi.pangaea.de/ 10.1594/PANGAEA.882599

\section{Authors' contributions}

IK and OR and WS designed the experiment. IK conducted the experiment, all laboratory and data analyses, supported by OR. IK, OR and WS wrote the manuscript. All authors have read and approved the publication of this manuscript.

\section{Ethics approval and consent to participate}

Experimental fish were bred from an A. burtoni stock originating from Chipwa at Lake Tanganyika, kept at the Zoological Institute of the University of Basel (Switzerland) under the permits $1010 \mathrm{H}$ and $\mathrm{CH}-\mathrm{I}-\mathrm{BS} 017$ issued by the cantonal veterinary office Basel. Experimental work was conducted in agreement with the German animal welfare law and approved by the Ministerium für Energiewende, Landwirtschaft, Umwelt, Natur und Digitalisierung under permission MELUR V 312-7224.121-19 (67-5/13), "komparative Vergleichsstudie von Immunantwort-Transfer von Eltern zu Nachkommen in Fischarten mit extremer Brutpflege").

\section{Consent for publication}

Not applicable.

\section{Competing interests}

The authors declare that they have no competing interests.

\section{Publisher's Note}

Springer Nature remains neutral with regard to jurisdictional claims in published maps and institutional affiliations.

\section{Author details}

${ }^{1}$ Evolutionary Ecology of Marine Fishes, GEOMAR - Helmholtz Centre for Ocean Research, Kiel, Germany. ${ }^{2}$ Zoological Institute, University of Basel, Basel, Switzerland.

Received: 9 March 2017 Accepted: 6 December 2017 Published online: 20 December 2017

References

1. Agrawal AA, Laforsch C, Tollrian R. Transgenerational induction of defences in animals and plants. Nature. 1999:401:60-3.

2. Alonso-Alvarez $C$, et al. Increased susceptibility to oxidative stress as a proximate cost of reproduction. Ecol Lett. 2004;7(5):363-8.

3. Avtalion RR, Mor A. Monomeric IgM is transferred from mother to egg in tilapias. Israeli Journal Of Aquaculture Bamidgeh. 1992;44(3):93-8. Available at: http://eurekamag.com/research/009/050/009050585.php\#.V-0WidllzC8. mendeley [Accessed 29 Sept 2016]

4. Badyaev AV, Uller T. Parental effects in ecology and evolution: mechanisms, processes and implications. Philos Trans R Soc Lond Ser B Biol Sci. 2009; 364(1520):1169-77. Available at: http://www.pubmedcentral.nih.gov/ articlerender.fcgi?artid=2666689\&tool=pmcentrez\&rendertype=abstract [Accessed 10 Nov 2013]

5. Baldo L, Santos ME, Salzburger W. Comparative transcriptomics of eastern African cichlid fishes shows signs of positive selection and a large contribution of untranslated regions to genetic diversity. Genome Biology and Evolution. 2011;3(1):443-55.

6. Bateman A, et al. UniProt: a hub for protein information. Nucleic Acids Res. 2015;43(D1):D204-12.

7. Bateman AJ. Intra-sexual selection in drosophila. Heredity. 1948;2:349-68.

8. Beemelmanns A \& Roth O, 2016a. Bacteria-type-specific biparental immune priming in the pipefish Syngnathus Typhle. Zoology, in press, pp.1-23. 
9. Beemelmanns A, Roth O. Biparental immune priming in the pipefish Syngnathus Typhle. Ecology and Evolution. 2016b;6(18):6735-57. Available at: http://dx.doi.org/10.1016/j.zool.2016.06.002

10. Berglund A, Rosenqvist G, Svensson I. Mate choice, fecundity and sexual dimorphism in two pipefish species (Syngnathidae). Behav Ecol Sociobiol. 1986;19(4):301-7.

11. Bly JE, Grimm AS, Morris IG. Transver of passive immunity from mother to young in a teleost fish: Haemagglutinating activity in the serum and eggs of place, pleuronectes platessa L. Comp Biochem Physiol. 1986;84A(2):309-13.

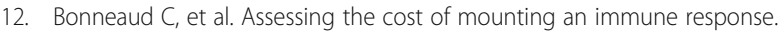
Am Nat. 2003;161(3):367-79. Available at: http://www.ncbi.nlm.nih.gov/ pubmed/12703483

13. Bourgeon S, Le Maho Y, Raclot T. Proximate and ultimate mechanisms underlying immunosuppression during the incubation fast in female eiders: roles of triiodothyronine and corticosterone. Gen Comp Endocrinol. 2009; 163(1-2):77-82. Available at: http://www.sciencedirect.com/science/article/ pii/S0016648008004140

14. Brawand $D$, et al. The genomic substrate for adaptive radiation in African cichlid fish. Nature. 2014;513:375-81.

15. Buschow SI, et al. MHC class II-associated proteins in B-cell exosomes and potential functional implications for exosome biogenesis. Immunol Cell Biol. 2010;88(8):851-6. Available at: http://dx.doi.org/10.1038/icb.2010.64.

16. Caratti $\mathrm{G}$, et al. Glucocorticoid receptor function in health and disease. Clin Endocrinol. 2015;83(4):441-8.

17. Choi KM, et al. Coagulation factor II from rock bream (Oplegnathus Fasciatus): first report on the molecular biological function and expression analysis in the teleost. Fish and Shellfish Immunology. 2016;48:145-53. Available at: http://dx.doi.org/10.1016/j.fsi.2015.11.028

18. Chong $\mathrm{K}$, et al. Characterisation of proteins in epidermal mucus of discus fish (Symphysodon spp.) during parental phase. Aquaculture. 2005;249(1-4): 469-76. Available at: http://linkinghub.elsevier.com/retrieve/pii/ S0044848605001304 [Accessed 14 Nov 2013]

19. Chong $K$, et al. Proteomics profiling of epidermal mucus secretion of a cichlid (Symphysodon Aequifasciata) demonstrating parental care behavior. Proteomics. 2006;6(7):2251-8. Available at: http://www.ncbi.nlm.nih.gov/ pubmed/16385477 [Accessed 14 Nov 2013]

20. Clutton-Brock T. In: Clutton-Brock T, editor. Reproductive success. Studies of individual variation in contrasting breeding systems. Chicago, London: The University of Chicago Press; 1988. Available at: http://doi.wiley.com/10.1046/ j.1420-9101.1990.3050478.x [Accessed 29 Sept 2016].

21. Deerenberg C, et al. Reproductive effort decreases antibody responsiveness. Proceedings of the Royal Society B-Biological Sciences. 1997;264(1384):1021-9.

22. Diepeveen ET, Roth O, Salzburger W. Immune-related functions of the Hivep gene family in east African cichlid fishes. G3 (Bethesda, Md). 2013;3:2205-17. Available at: http://www.pubmedcentral.nih.gov/articlerender.fcgi?artid= 3852383\&tool=pmcentrez\&rendertype=abstract. Accessed 14 Nov 2013.

23. Dijkstra PD, et al. Social stimulation, nuptial colouration, androgens and immunocompetence in a sexual dimorphic cichlid fish. Behav Ecol Sociobiol. 2006;61(4):599-609. Available at: http://www.springerlink.com/ index/10.1007/s00265-006-0289-7 [Accessed 7 Nov 2012]

24. Egger B, Roest M, Böhne A, Roth O, Salzburger W. Demography and genome divergence of lake and stream populations of an east African cichlid fish. Mol Ecol. 2017;26:5016-30.

25. Fedorka KM, Zuk M, Mousseau TA. Immune suppression and the cost of reproduction in the ground cricket, Allonemobius Socius. Evolution. 2004; 58(11):2478-85. Available at: https://www.ncbi.nlm.nih.gov/pubmed/15612291.

26. Fernald RD, Hirata NR. The ontogeny of social behavior and body coloration in the african cichlid fish haplochromis burtoni. Zeitschrif für Tierpsychologie. 1979;50:180-7.

27. Foey A, Picchietti S. Immune defences of teleost fish. Aquacultures Nutr: Gut Health, Probiotics, Prebiotics. 2014;2:14-52

28. Foo JTW, Lam TJ. Retardation of ovarian growth and depression of serum steroid levels in the tilapia, Oreochromis Mossambicus, by cortisol implantation. Aquacultrue. 1993;115:133-43.

29. French SS, Johnston GIH, Moore MC. Immune activity suppresses reproduction in food-limited female tree lizards Urosaurus Ornatus. Funct Ecol. 2007;21(6):1115-22.

30. Galindo-Villegas J, et al. Recombinant TNFa as oral vaccine adjuvant protects European sea bass against vibriosis: insights into the role of the CCL25/CCR9 axis. Fish and Shellfish Immunology. 2013;35(4):1260-71. Available at: http://dx.doi.org/10.1016/j.fsi.2013.07.046
31. Giacomello E, Marchini D, Rasotto MB. A male sexually dimorphic trait provides antimicrobials to eggs in blenny fish. Biol Lett. 2006;2(3):330-3. Available at: http://www.pubmedcentral.nih.gov/articlerender.fcgi?artid= 1686180\&tool=pmcentrez\&rendertype=abstract [Accessed 7 Nov 2012]

32. Grindstaff $J$, et al. Transgenerational priming of immunity: maternal exposure to a bacterial antigen enhances offspring humoral immunity. Proceedings. Biological sciences / The Royal Society. 2006;273(1600):2551-7. Available at: http://www.pubmedcentral.nih.gov/articlerender.fcgi?artid= 1634911\&tool=pmcentrez\&rendertype=abstract [Accessed 6 Nov 2012]

33. Grindstaff $\lrcorner$, Brodie ED, Ketterson ED. Immune function across generations: integrating mechanism and evolutionary process in maternal antibody transmission. Proceedings. Biological sciences / The Royal Society. 2003; 270(1531):2309-19. Available at: http://www.pubmedcentral.nih.gov/ articlerender.fcgi?artid=1691520\&tool=pmcentrez\&rendertype=abstract [Accessed 31 Jan 2013]

34. Gross MR, Sargent RC. The evolution of male and female parental care in fishes. Am Zool. 1985;25:807-22.

35. Grüter $C$, Taborsky B. Mouthbrooding and biparental care: an unexpected combination, but male brood care pays. Anim Behav. 2004;68(6):1283-9. Available at: http://linkinghub.elsevier.com/retrieve/pii/S0003347204003008 [Accessed 7 Jan 2013]

36. Hamilton WD, Zuk M. Heritable true fitness and bright birds: a role for parasites? Science. 1982;218:384-6.

37. Harris J, Bird DJ. Modulation of the fish immune system by hormones. Vet Immunol Immunopathol. 2000;77(3-4):163-76. Available at: http://www. ncbi.nlm.nih.gov/pubmed/11137116.

38. Hasselquist D, Nilsson J-A. Maternal transfer of antibodies in vertebrates: trans-generational effects on offspring immunity. Philos Trans R Soc Lond Ser B Biol Sci. 2009;364(1513):51-60. Available at: http://www. pubmedcentral.nih.gov/articlerender.fcgi?artid=2666691\&tool= pmcentrez\&rendertype=abstract [Accessed 1 Nov 2012]

39. Henning F, Meyer A. Eggspot number and sexual selection in the cichlid fish Astatotilapia Burtoni. PLoS One. 2012;7(8):e43695. Available at: http:// www.pubmedcentral.nih.gov/articlerender.fcgi?artid=3427294\&tool= pmcentrez\&rendertype=abstract [Accessed 1 Mar 2013]

40. Heule C, Salzburger W. The ontogenetic development of egg-spots in the haplochromine cichlid fish Astatotilapia Burtoni. J Fish Biol. 2011; 78(5):1588-93. Available at: http://www.ncbi.nlm.nih.gov/pubmed/ 21539562 [Accessed 18 Mar 2013]

41. Ho DH, Burggren WW. Epigenetics and transgenerational transfer: a physiological perspective. J Exp Biol. 2010;213(1):3-16. Available at: http:// www.ncbi.nlm.nih.gov/pubmed/20008356 [Accessed 3 Mar 2015].

42. Huffman, L.S., Crews, D. \& Gore, A.C., 2011. Molecular mechanisms of phenotypic plasticity in Astatotilapia burtoni.

43. Iq KC, Shu-Chien AC. Proteomics of buccal cavity mucus in female tilapia fish (oreochromis spp.): a comparison between parental and non-parental fish. PLoS One. 2011;6(4):2-8.

44. Keenleyside MHA. Parental care. In: Keenleyside MHA, editor. Cichlid fishes: behaviour, ecology and evolution. Cambridge: Chapman \& Hall; 1991. p. 191-208.

45. Kidd MR, et al. Female preference for males depends on reproductive physiology in the African cichlid fish Astatotilapia Burtoni. Gen Comp Endocrinol. 2013;180: 56-63. Available at: http://www.ncbi.nlm.nih.gov/pubmed/23168085 [Accessed 8 Mar 2013]

46. Kirkpatrick M, Lande R. The evolution of maternal characters. Evolution. 1989;43(3):485-503.

47. Knowles SCL, Nakagawa S, Sheldon BC. Elevated reproductive effort increases blood parasitaemia and decreases immune function in birds: a meta-regression approach. Funct Ecol. 2009;23(2):405-15.

48. Kurtz J, et al. Gender differences and individual variation in the immune system of the scorpionfly Panorpa Vulgaris (Insecta: Mecoptera). Dev Comp Immunol. 2000;24(1):1-12.

49. Lessells CM. A theoretical framework for sex-biased parental care. Anim Behav. 1998;56(Williams 1966):395-407. Available at: http://www.ncbi.nIm. nih.gov/pubmed/9787031

50. Levy S, Todd SC, Maecker HT. CD81 (TAPA-1): a molecule involved in signal transduction and cell adhesion in the immune system. Annu Rev Immunol. 1998;16:89-109.

51. Li M, Leatherland JF. The interaction between maternal stress and the ontogeny of the innate immune system during teleost embryogenesis: implications for aquaculture practice. J Fish Biol. 2012;81 (6):1793-814. 
52. Lim PS, et al. Epigenetic regulation of inducible gene expression in the immune system. Immunology. 2013;139(3):285-93.

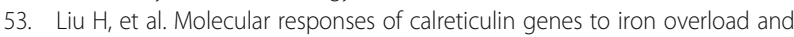
bacterial challenge in channel catfish (Ictalurus Punctatus). Dev Comp Immunol. 2011;35(3):267-72. Available at: http://dx.doi.org/10.1016/j.dci. 2010.11.009

54. Magnadóttir B. Innate immunity of fish (overview). Fish \& shellfish immunology. 2006;20(2):137-51. Available at: http://www.ncbi.nlm.nih.gov/pubmed/15950491 [Accessed 29 Oct 2012]

55. Maruska KP. Social regulation of reproduction in male cichlid fishes. Gen Comp Endocrinol. 2014;207:2-12. Available at: http://www.sciencedirect. com/science/article/pii/S0016648014001907

56. Maruska KP, Ung US, Fernald RD. The African cichlid fish Astatotilapia burtoni uses acoustic communication for reproduction: sound production, hearing, and behavioral significance. PLoS One. 2012;7(5):e37612. Available at: http://www.pubmedcentral.nih.gov/articlerender.fcgi?artid= 3356291\&tool=pmcentrez\&rendertype=abstract. Accessed 1 Mar 2013.

57. Milani $V$, et al. Heat shock protein 70: role in antigen presentation and immune stimulation. Int J Hyperth. 2002;18(6):563-75.

58. Milla $S$, Depiereux $S$, Kestemont $P$. The effects of estrogenic and androgenic endocrine disruptors on the immune system of fish: a review. Ecotoxicology. 2011;20(2):305-19.

59. Mor A, Avtalion RR. Transfer of antibody activity from immunized mother to embryo in tilapias. J Fish Biol. 1990;37:249-55.

60. Mousseau TA, Fox CW. The adaptive significance of maternal effects. Trends Ecol Evol. 1998;13(October):403-7.

61. Mrowka W, Schierwater B. Energy expenditure for mouthbrooding in a cichlid fish. Behav Ecol Sociobiology. 1988;(22):161-4

62. Muñoz IM, et al. Family with sequence similarity 60A (FAM60A) protein is a cell cycle-fluctuating regulator of the SIN3-HDAC1 histone deacetylase complex. J Biol Chem. 2012;287(39):32346-53.

63. Nordling $D$, et al. Reproductive effort reduces specific immune response and parasite resistance. Proc R Soc B Biol Sci. 1998;265(1403):1291-8. Available at: http://rspb.royalsocietypublishing.org/cgi/doi/10.1098/rspb. 1998.0432

64. Nottke A, Colaiácovo MP, Shi Y. Developmental roles of the histone lysine demethylases. Development (Cambridge, England). 2009;136:879-89.

65. Parkin J, Cohen B. An overview of the immune system. Lancet. 2001; 357(9270):1777-89.

66. Pérez-Rodríguez L. Carotenoids in evolutionary ecology: re-evaluating the antioxidant role. BioEssays. 2009;31(10):1116-26.

67. Pizzolon $\mathrm{M}$, et al. When fathers make the difference: efficacy of male sexually selected antimicrobial glands in enhancing fish hatching success. Funct Ecol. 2010;24(1):141-8. Available at: http://onlinelibrary.wiley.com/doi/ 10.1111/j.1365-2435.2009.01608.x/abstract. Accessed 24 Jan 2013.

68. Reardon EE, Chapman $\sqcup$. Hypoxia and energetics of mouth brooding: is parental care a costly affair? Comp Biochem Physiol A Mol Integr Physiol. 2010;156(4):400-6. Available at: http://www.ncbi.n/m.nih.gov/pubmed/20227513 [Accessed 8 Mar 2013]

69. Reul JMHM, et al. Prenatal immune challenge alters the hypothalamicpituitary-adrenocortical axis in adult rats. J Clin Investig. 1994;93(6):2600-7.

70. Reyes-López FE, et al. Differential immune gene expression profiles in susceptible and resistant full-sibling families of Atlantic salmon (Salmo Salar) challenged with infectious pancreatic necrosis virus (IPNV). Developmental \& Comparative Immunology. 2015;53(1):210-21. Available at: http:// linkinghub.elsevier.com/retrieve/pii/S0145305X15001378

71. Rolff J. Bateman's principle and immunity. Proc R Soc B Biol Sci. 2002; 269(1493):867-72. Available at: http://rspb.royalsocietypublishing.org/cgi/ doi/10.1098/rspb.2002.1959

72. Roth $\mathrm{O}$, et al. Bateman's principle and immunity in a sex-role reversed pipefish. J Evol Biol. 2011;24(7):1410-20. Available at: http://www.ncbi.nlm. nih.gov/pubmed/21545418 [Accessed 14 Nov 2013]

73. Roth O, Keller I, et al. Hosts are ahead in a marine host-parasite coevolutionary arms race: innate immune system adaptation in pipefish syngnathus typhle against vibrio phylotypes. Evolution. 2012a;66(8):2528-39.

74. Roth $\mathrm{O}$, Klein $\mathrm{V}$, et al. Male pregnancy and biparental immune priming. Am Nat. 2012b;180(6):802-14. Available at: https://www.ncbi.nlm.nih.gov/ pubmed/23149404. Accessed 1 Mar 2013.

75. Roth $\mathrm{O}$, Kurtz J. The stimulation of immune defence accelerates development in the red flour beetle (Tribolium Castaneum). J Evol Biol. 2008;21(6):1703-10.
76. Salzburger W, et al. Annotation of expressed sequence tags for the east African cichlid fish Astatotilapia Burtoni and evolutionary analyses of cichlid ORFs. BMC Genomics. 2008;9:96.

77. Santos ME, et al. The evolution of cichlid fish egg-spots is linked with a cisregulatory change. Nat Commun. 2014;5:5149. Available at: http://www. nature.com/ncomms/2014/141009/ncomms6149/full/ncomms6149.html

78. Sheldon BC, Verhulst S. Ecological immunology; costly parasite defences and trade-offs in evolutionary ecology. Trends Ecol Evol. 1996;11(8):317-21. Available at: https://www.ncbi.nlm.nih.gov/pubmed/21237861

79. Sin YM, Ling KH, Lam TJ. Passive transfer of protective immunity against ichthyophthiriasis from vaccinated mother to fry in tilapias, Oreochromis Aureus. Aquaculture. 1994;120:229-37.

80. Siva-Jothy MT. A mechanistic link between parasite resistance and expression of a sexually selected trait in a damselfly. Proceedings Biological sciences / The Royal Society. 2000;267(1461):2523-7. Available at: http:// www.pubmedcentral.nih.gov/articlerender.fcgi?artid=1690847\&tool= pmcentrez\&rendertype=abstract

81. Skarstein F, Folstad I, Liljedal S. Whether to reproduce or not: immune suppression and costs of parasites during reproduction in the Arctic charr. Canadian Journal of Zoology-Revue Canadienne De Zoologie. 2001;79(2):271-8.

82. Smith C, Wooton RJ. The cost of parental care in teleost fishes. Rev Fish Biol Fish. 1995;5:7-22.

83. Smith $\mathrm{KT}$, et al. Human family with sequence similarity 60 member a (FAM60A) protein: a new subunit of the Sin3 Deacetylase complex. Mol Cell Proteomics. 2012;11(12):1815-28. Available at: http://www.mcponline.org/ cgi/doi/10.1074/mcp.M112.020255

84. Stearns SC. The selection-arena hypothesis. In: Stearns SC, editor. The evolution of sex and its consequences. Basel \& Boston: Birkhäuser Verlag; 1987. p. 337-55.

85. Stoehr AM, Kokko H. Sexual dimorphism in immunocompetence: what does life-history theory predict? Behav Ecol. 2006;17(5):751-6. Available at: https://academic.oup.com/beheco/article/17/5/751/206829. Accessed 24 Mar 2015.

86. Stolte $\mathrm{EH}$, et al. Stress and innate immunity in carp: corticosteroid receptors and pro-inflammatory cytokines. Mol Immunol. 2008;46(1):70-9.

87. Suzuki Y, et al. Reproduction related immunoglobulin changes in rainbow trout. Fish Physiol Biochem. 1997;17(1):415-21. Available at: http://dx.doi. org/10.1023/A:1007795827112

88. Swain P, Nayak SK. Role of maternally derived immunity in fish. Fish \& shellfish immunology. 2009;27(2):89-99. Available at: http://www.ncbi.nlm. nih.gov/pubmed/19442742 [Accessed 7 Jan 2013]

89. Takemura A, Takano K. Transfer of maternally-derived immunoglobulin ( IgM ) to larvae in tilapia, Oreochromis Mossambicus. Fish \& Shellfish Immunology. 1997;7:355-63.

90. Theis A, et al. Adaptive divergence between lake and stream populations of an east African cichlid fish. Mol Ecol. 2014;23(21):5304-22. Available at: http://doi.wiley.com/10.1111/mec.12939

91. Theis $\mathrm{A}$, et al. Variation of anal fin egg-spots along an environmental gradient in a haplochromine cichlid fish. Evolution, pp. 2017:1-12. Available at: http://doi.wiley.com/10.1111/evo.13166.

92. Theis A, Salzburger W, Egger B. The function of anal fin egg-spots in the cichlid fish Astatotilapia Burtoni. PLoS One. 2012;7(1):e29878. Available at: http://www.pubmedcentral.nih.gov/articlerender.fcgi?artid=3252332\&tool= pmcentrez\&rendertype $=$ abstract [Accessed 12 Nov 2012]

93. Trivers RL. Parental investment and sexual selection. In: Campbell B, editor. Sexual selection and the descent of man. Chicago, Illinois: Aldine Publishing Company; 1972. p. 136-79

94. Uehara S, et al. A role for CCR9 in T lymphocyte development and migration. J Immunol. 2002;168(6):2811-9.

95. Uller T. Developmental plasticity and the evolution of parental effects. Cell. 2008;23(8):432-8. Available at: http://www.ncbi.n/m.nih.gov/pubmed/ 18586350. Accessed 10 Nov 2013.

96. Uribe $\mathrm{C}$, et al. Innate and adaptive immunity in teleost fish: a review. 2011. 56(10):486-503.

97. Wang $C$, et al. Fish \& Shell fi sh immunology the role of catalase in the immune response to oxidative stress and pathogen challenge in the clam Meretrix meretrix. Fish and Shellfish Immunology. 2013;34(1):91-9. Available at: http://dx.doi.org/10.1016/j.fsi.2012.10.013

98. West-Eberhard MJ. Developmental plasticity and evolution. Nature. 2003; 424:794. 
99. Yang $\mathrm{H}$, et al. Expression pattern of early growth response gene 1 during olive flounder ( Paralichthys Olivaceus ) embryonic development. Development \& Reproduction. 2014;18(4):233-40.

100. Zhang S, Wang Z, Wang H. Maternal immunity in fish. Dev Comp Immunol. 2013;39(1-2):72-8. Available at: http://www.ncbi.nlm.nih.gov/pubmed/ 22387589 [Accessed 24 Jan 2013].

Submit your next manuscript to BioMed Central and we will help you at every step:

- We accept pre-submission inquiries

- Our selector tool helps you to find the most relevant journal

- We provide round the clock customer support

- Convenient online submission

- Thorough peer review

- Inclusion in PubMed and all major indexing services

- Maximum visibility for your research

Submit your manuscript at www.biomedcentral.com/submit 